\title{
Titanium $\sigma$-acetylides as building blocks for heterobimetallic transition metal complexes: synthesis and redox behaviour of $\pi$-conjugated organometallic systems ${ }^{\text {is }}$
}

\author{
Stephan Back ${ }^{\mathrm{a}, \mathrm{b}}$, Robert A. Gossage ${ }^{\mathrm{a}}$, Gerd Rheinwald ${ }^{\mathrm{b}}$, Ignacio del Río ${ }^{\mathrm{a}}$, Heinrich Lang ${ }^{\mathrm{b}, *}$, \\ Gerard van Koten ${ }^{\mathrm{a}, 1}$ \\ a Debye Institute, Department of Metal-Mediated Synthesis, Utrecht University, Padualaan 8, NL-3584 CH Utrecht, Netherlands \\ ${ }^{\mathrm{b}}$ Technische Universität Chemnitz, Institut für Chemie, Lehrstuhl Anorganische Chemie, Straße der Nationen 62, D-09111 Chemnitz, Germany
}

Received 4 August 1998

\begin{abstract}
A series of related $\mathrm{Ti} \sigma$-acetylides of the type $\{\mathrm{Ti}\} \mathrm{C} \equiv \mathrm{CR} \quad\left(\{\mathrm{Ti}\}=\left(\eta^{5}-\mathrm{C}_{5} \mathrm{H}_{5}\right)_{2} \mathrm{Ti}_{(}\left(\mathrm{CH}_{2} \mathrm{SiMe}_{3}\right) ; 2: \quad \mathrm{R}=\mathrm{SiMe}_{3} ; \quad 3: \mathrm{R}=\right.$ $\mathrm{C}_{6} \mathrm{H}_{3}\left(\mathrm{CH}_{2} \mathrm{NMe}_{2}\right)_{2}-3,5 ; 4: \mathrm{R}=\mathrm{C}_{6} \mathrm{H}_{2} \mathrm{I}-4-\left(\mathrm{CH}_{2} \mathrm{NMe}_{2}\right)_{2}-3,5 ; 5: \mathrm{R}=\mathrm{C}_{6} \mathrm{H}_{4} \mathrm{CN}-4 ; 6: \mathrm{R}=\mathrm{C}_{5} \mathrm{H}_{4} \mathrm{~N}-4 ; 7: \mathrm{R}=\mathrm{Fc}, \mathrm{Fc}=\left(\eta^{5}-\mathrm{C}_{5} \mathrm{H}_{4}\right) \mathrm{Fe}\left(\eta^{5}-\right.$ $\left.\left.\mathrm{C}_{5} \mathrm{H}_{5}\right) ; 8: \mathrm{R}=\mathrm{C}_{6} \mathrm{H}_{4}(\mathrm{C} \equiv \mathrm{C}\{\mathrm{Ti}\})-4\right)$ have been prepared by reacting the corresponding lithium acetylides with $\{\mathrm{Ti}\} \mathrm{Cl}(\mathbf{1})$. The X-ray crystal structure determination of $\{\mathrm{Ti}\} \mathrm{C} \equiv \mathrm{CSiMe}_{3}(2)$ is reported. This compound exhibits a one-dimensional (1D) arrangement with respect to the $\mathrm{Ti}-\mathrm{C} \equiv \mathrm{C}$ unit. The reaction of $\mathbf{2}$ with $[\mathrm{CuCl}]_{n}$ afforded $\mathbf{1}$ and $\left[\mathrm{CuC} \equiv \mathrm{CSiMe}_{3}\right]_{n}(\mathbf{1 0})$ and is proposed to occur via prior formation of the dimeric intermediate $\left[\left(\eta^{2}-\{\mathrm{Ti}\} \mathrm{C} \equiv \mathrm{CSiMe}_{3}\right)_{2} \mathrm{Cu}_{2} \mathrm{Cl}_{2}\right]$. The chemical oxidation of $\{\mathrm{Ti}\} \mathrm{C} \equiv \mathrm{CFc}, 7$, with $\mathrm{Ag}\left[\mathrm{BF}{ }_{4}\right]$ yielded $\mathrm{HC} \equiv \mathrm{CFc}$ and an undefined Ti species. Treatment of $\mathbf{5}$ or $\mathbf{6}$ with $\{\mathrm{Ru}\} \mathrm{N} \equiv \mathrm{N}\{\mathrm{Ru}\} \quad\left(\{\mathrm{Ru}\}=m e r\right.$, trans $-\left[\mathrm{RuCl}_{2}\left(\mathrm{NN}^{\prime} \mathrm{N}\right)\right]$; $\left.\mathrm{NN}^{\prime} \mathrm{N}=\eta^{3}-\mathrm{C}_{5} \mathrm{H}_{3} \mathrm{~N}\left(\mathrm{CH}_{2} \mathrm{NMe}_{2}\right)_{2}-2,6\right)$ produced intensively coloured heterodinuclear compounds, such as $\left[\{\mathrm{Ti}\} \mathrm{C} \equiv \mathrm{CC}_{5} \mathrm{H}_{4} \mathrm{~N}-4\right]\{\mathrm{Ru}\}$ (16). In contrast, 5 and 6 react with cationic Pt compounds of the type $[\{\mathrm{Pt}\} \cdot \mathrm{L}][\mathrm{X}]\left(\{\mathrm{Pt}\}=\left[\mathrm{Pt}\left(\mathrm{C}_{6} \mathrm{H}_{3}\left\{\mathrm{CH}_{2} \mathrm{NMe}_{2}\right\}_{2}-2,6\right]^{+} ; \mathrm{L}=\mathrm{H}_{2} \mathrm{O}\right.\right.$, $\left.\mathrm{MeCN} ; \mathrm{X}=\mathrm{BF}_{4}, \mathrm{OTf}\right)$ to give product mixtures rather than defined compounds. Electrochemical studies on some of the bimetallic compounds show that the $\mathrm{Ti}(\mathrm{III}) / \mathrm{Ti}(\mathrm{IV})$ redox potential appears to be reversible and is shifted to a more negative value upon substitution of the $\mathrm{Cl}$ ligand in $\mathbf{1}$ by $\mathrm{C} \equiv \mathrm{CR}$ (compounds $\mathbf{2}-\mathbf{8}$ ). Whereas the nature of $\mathrm{R}$ in $\{\mathrm{Ti}\} \mathrm{C} \equiv \mathrm{CR}$ has an influence on the $\mathrm{Ti}(\mathrm{III}) / \mathrm{Ti}(\mathrm{IV})$ redox potential, the attachment of a second metal onto the $\pi$-conjugated system has only negligible effect on the electrochemical properties of the Ti centre. (C) 1998 Elsevier Science S.A. All rights reserved.
\end{abstract}

Keywords: Metallocenes; Alkynes; Metal-metal interaction; Conjugation; Cyclic voltammetry

\section{Introduction}

Transition metal (TM) complexes in which metal centers are linked by linear $\pi$-conjugated organic systems (e.g. $\sigma$-bonded alkynyl ligands) are currently studied due to their potential as new materials which may

\footnotetext{
Dedicated to Professor Alan Cowley on the occasion of his 65th birthday.

* Corresponding author. Fax: +49-371-5311833.

${ }^{1}$ Also corresponding author. Fax: + 31-30-252 3615.

E-mail addresses: heinrich.lang@chemie.tu-chemnitz.de (H. Lang); g.vankoten@chem.uu.nl (G. van Koten)
}

possess novel and/or interesting electronic properties [1]. These conjugated organic systems allow electronic interaction or communication between attached metal centres and can impose a one-dimensional (1D) directionality. Such organometallic complexes resemble classical organic non-linear optical (NLO) compounds, e.g. para-nitroaniline [2], in which electron donor and acceptor units are connected via a conjugated $\pi$-system [3]. The 1D organometallic complexes which are currently used in NLO studies can be divided into three main groups: (i) complexes containing a central late TM complex fragment and one or two conjugated 
electron donator/acceptor units bonded to it [4], (ii) two late TM complex fragments linked by a $\pi$-conjugated chain [5] and (iii) three or more late $\mathrm{TM}$ complex fragments incorporated into a $\pi$-conjugated system [6]. However, only a few examples of heterobimetallic complexes have been reported in which an early (e.g. Ti, Zr, Hf) and a late TM unit are connected by a $\pi$-conjugated organic system [7].
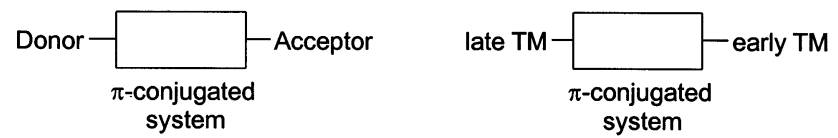

This latter class of compounds is thought to have the most interesting electronic properties. One can assume that an early TM complex fragment with the metal atom in a high oxidation state, e.g. titanocene derivatives containing a $\mathrm{Ti}(\mathrm{IV})$ metal centre, can function as an electron acceptor unit due to (energetically low lying) vacant molecular orbitals [8]. A late TM complex fragment with the metal centre in a low oxidation state [e.g. $\mathrm{Fe}(\mathrm{II}), \mathrm{Pt}(\mathrm{II})$ or $\mathrm{Ru}(\mathrm{II})$ ] could therefore act as an electron donor unit. If both of these entities are connected via a conjugated $\pi$-system which supports electronic communication, e.g. acetylide units, then this could result in changes in the two metal centres with respect to their individual electronic behaviour. Previously, it has been shown by cyclic voltammetric experiments that the electron density of a Ti(IV) centre in titanocene derivatives can be influenced by the acetylide substituents [9]. In order to ensure 1D directionality, one of the two reactive sites of the electron accepting titanocene fragment should be blocked and this leads to the $\{\mathrm{Ti}\}$ unit $\left[\{\mathrm{Ti}\}=\left(\eta^{5}-\mathrm{C}_{5} \mathrm{H}_{5}\right)_{2} \mathrm{TiR} ; \mathrm{R}=\right.$ blocking anion]. This will permit the synthesis of titanocene monoacetylides. The acetylenic units linked to Ti are of two types: the first class incorporates further potentially ligating sites, such as 4-pyridyl or 4-benzonitrile groups. These sites can be used as linkage to a number of different late $\mathrm{TMs}$, e.g. $\mathrm{Pt}(\mathrm{II})$ or $\mathrm{Ru}(\mathrm{II})$ containing fragments. The second class incorporates a late TM complex fragment directly, i.e. an organometallic acetylide. A third possibility for the build-up of multimetallic systems is offered by the presence of a $\mathrm{C} \equiv \mathrm{C}$ triple bond of the acetylenic unit itself. Its coordination chemistry to TM complexes, e.g. $\mathrm{Cu}(\mathrm{I})$, is well known and a number of compounds, in which an acetylide is $\eta^{2}$-coordinated to a $\mathrm{Cu}(\mathrm{I})$ centre, has been reported [10]. This latter approach does not result in a 1D but a $2 \mathrm{D}$ arrangement of the respective metal atoms and can also be used to give some insight into the stability of the Ti acetylide $\sigma$-bond. Moreover, this allows for the possibility to influence an early-late $\mathrm{TM}$ interaction directly via coordination of the bridging $\mathrm{C} \equiv \mathrm{C}$ unit. These heterometallic compounds will allow the investigation of early-late TM interaction along organic $\pi$ conjugated fragments. Thus, an attempt is made to use such multimetallic molecules as molecular dipoles and/ or model compounds for 'nanoconducting' materials.

\section{Results and discussion}

\subsection{Synthesis of titanium mono-acetylides}

The titanocene monochloride $\{\mathrm{Ti}\} \mathrm{Cl}(\mathbf{1})\left\{\{\mathrm{Ti}\}=\left(\eta^{5}-\right.\right.$ $\left.\left.\mathrm{C}_{5} \mathrm{H}_{5}\right)_{2} \mathrm{Ti}\left(\mathrm{CH}_{2} \mathrm{SiMe}_{3}\right)\right\}$ is obtained in high yield by the reaction of titanocene dichloride with neosilyl magnesium chloride [11]. This reaction serves as the basis for the preparation of a series of titanocene monoacetylides, which are virtually $1 \mathrm{D}$ with respect to the Ti-acetylide unit. The synthesis of compounds $\mathbf{2}-\mathbf{8}$ (Eq. 1) was conducted following well-documented procedures for the build-up of titanocene bis(acetylides) [12]. Compounds $2-6$ and 8 were obtained as yellow to orange solids $\left(60-80 \%\right.$ yield) which are stable at $25^{\circ} \mathrm{C}$ if stored under a nitrogen atmosphere. Compound 7 exhibits an intensively purple colour. Analogous intensive colours have been obtained for bis(alkynyl) titanocenes carrying ferrocenyl $(\mathrm{Fc})$ as terminal group of the acetylide units [7]. The FAB mass spectroscopic investigation of the Ti acetylides $\mathbf{2}-\mathbf{8}$ revealed a peak for the molecular ion $[\mathrm{M}]^{+}$at the expected $m / z$ values in addition to the expected fragmentation patterns.

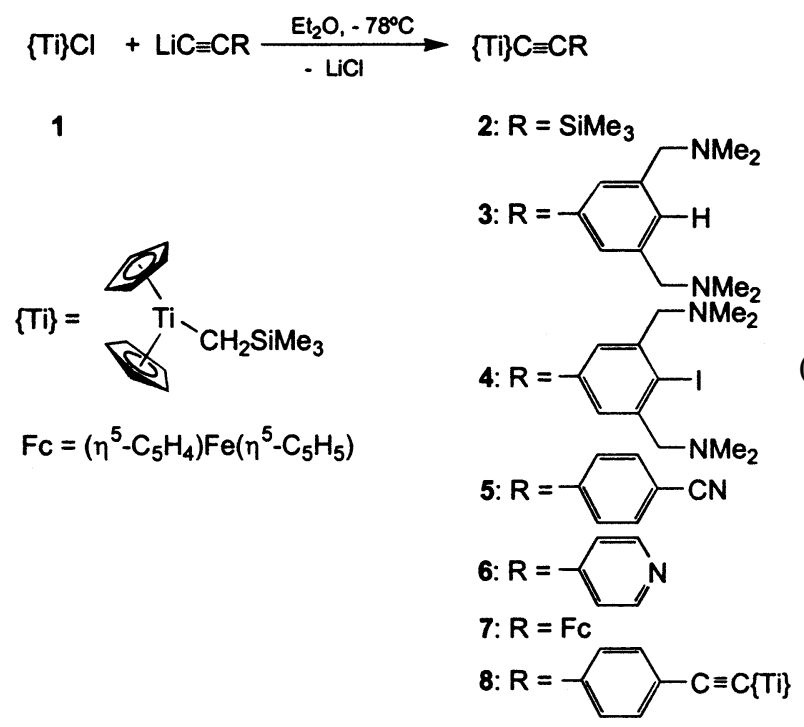

The $\mathrm{C} \equiv \mathrm{C}$ stretching vibration in the IR spectrum is the most informative spectroscopic tool for monitoring the progress of the reaction. While the corresponding free acetylenes have a $v_{\mathrm{C} \equiv \mathrm{C}}$ vibration in the range of 2100 and $2110 \mathrm{~cm}^{-1}$, compounds $3-8$ exhibit $v_{\mathrm{C}=\mathrm{C}}$ vibrations around $2070 \mathrm{~cm}^{-1}$ (Table 1). In the IR spectrum of $\mathbf{2}$, this absorption appears at much lower frequency (2017 $\mathrm{cm}^{-1}$ ). These values resemble the data obtained for bis(alkynyl) titanocenes of the type $\left(\eta^{5}-\right.$ $\left.\mathrm{C}_{5} \mathrm{H}_{4} \mathrm{SiMe}_{3}\right)_{2} \mathrm{M}(\mathrm{C} \equiv \mathrm{CR})_{2} \quad(\mathrm{M}=\mathrm{Ti}, \quad \mathrm{Zr}, \quad \mathrm{Hf}$, e.g. $\mathrm{R}=$ 
Table 1

Representative spectroscopic data (IR, ${ }^{1} \mathrm{H}$ and ${ }^{13} \mathrm{C}\left\{{ }^{1} \mathrm{H}\right\}-\mathrm{NMR}$ ) of the Ti acetylides 2-8 and $\{\mathrm{Ti}\} \mathrm{Cl}$ (1) for comparison

\begin{tabular}{|c|c|c|c|c|c|c|c|c|}
\hline \multirow{2}{*}{$\begin{array}{l}\{\mathrm{Ti}\} \mathrm{C} \equiv \mathrm{CR} \\
\mathrm{R}=\end{array}$} & & \multirow[t]{2}{*}{$\mathrm{IR}^{\mathrm{a}}$} & \multicolumn{2}{|c|}{${ }^{1} \mathrm{H}-\mathrm{NMR}^{\mathrm{b}}$} & \multicolumn{4}{|c|}{${ }^{13} \mathrm{C}\left\{{ }^{1} \mathrm{H}\right\}-\mathrm{NMR}^{\mathrm{c}}$} \\
\hline & & & $\mathrm{C}_{5} H_{5}$ & $\mathrm{TiCH}_{2}$ & $C_{5} \mathrm{H}_{5}$ & $\mathrm{TiCH}$ & $\mathrm{Ti} C \equiv \mathrm{C}$ & $\mathrm{TiC} \equiv C$ \\
\hline$\{\mathrm{Ti}\} \mathrm{Cl}$ & 1 & - & 6.31 & 2.18 & 115.6 & 79.7 & - & - \\
\hline $\mathrm{SiMe}_{3}$ & 2 & 2017 & 6.22 & 1.60 & 113.0 & 81.2 & 164.6 & 128.6 \\
\hline $\mathrm{C}_{6} \mathrm{H}_{3}\left(\mathrm{CH}_{2} \mathrm{NMe}_{2}\right)_{2}-3,5$ & 3 & 2069 & 6.27 & 1.64 & 112.9 & 81.0 & 143.7 & 123.9 \\
\hline $\mathrm{C}_{6} \mathrm{H}_{2} \mathrm{I}-4-\left(\mathrm{CH}_{2} \mathrm{NMe}_{2}\right)_{2}-3,5$ & 4 & 2069 & 6.27 & 1.64 & 112.9 & 81.0 & 143.7 & 123.8 \\
\hline $\mathrm{C}_{6} \mathrm{H}_{4} \mathrm{CN}-4$ & 5 & 2078 & 6.29 & 1.75 & 113.1 & 83.8 & 148.8 & 122.2 \\
\hline $\mathrm{C}_{5} \mathrm{H}_{4} \mathrm{~N}-4$ & 6 & 2079 & 6.25 & 1.72 & 113.2 & 83.7 & 148.9 & 121.0 \\
\hline $\mathrm{Fc}$ & 7 & 2052 & 6.25 & 1.57 & 112.7 & 77.7 & 140.1 & 122.8 \\
\hline $\mathrm{C}_{6} \mathrm{H}_{4} \mathrm{C} \equiv \mathrm{C}\{\mathrm{Ti}\}-4$ & 8 & 2076 & 6.27 & 1.65 & 112.9 & 81.5 & 140.1 & 124.3 \\
\hline
\end{tabular}

\footnotetext{
${ }^{\text {a }}$ Recorded in $\mathrm{KBr}\left(\mathrm{cm}^{-1}\right)$.

${ }^{\mathrm{b}}$ Relative to $\mathrm{SiMe}_{4}(\delta=0.00 \mathrm{ppm})$.

${ }^{\mathrm{c}}$ Relative to $\mathrm{SiMe}_{4}(\delta=0.00 \mathrm{ppm})$. Chemical shifts are reported in $\delta$ units (ppm) downfield from $\mathrm{SiMe}_{4}$ with the solvent as internal reference signal.
}

$\mathrm{SiMe}_{3}$ [13], $\mathrm{Ph}$ [14], Fc [7]) and indicate likewise a weakening of the $\mathrm{C} \equiv \mathrm{C}$ bond upon binding to $\mathrm{Ti}[15,16]$.

The comparison of the ${ }^{1} \mathrm{H}-\mathrm{NMR}$ spectrum of 1 with those of complexes 2-8 reveals that the signals of the protons of the $\mathrm{C}_{5} \mathrm{H}_{5}$ group appear at virtually the same frequency, while those of the methylene protons of the neosilyl group are shifted by ca. $0.5 \mathrm{ppm}$ to higher field (Table 1). The resonance signals of the protons of the other organic fragments were found in the expected regions as sharp and well-resolved signals. In the ${ }^{13} \mathrm{C}\left\{{ }^{1} \mathrm{H}\right\}$-NMR spectra of $\mathbf{2}-\mathbf{8}$, the resonance signals of the $\mathrm{C}_{5} \mathrm{H}_{5}$ and $\mathrm{CH}_{2} \mathrm{Si}$ units are only slightly shifted to higher field relative to those of the starting material 1 (Table 1). In general, by substitution of the $\mathrm{Cl}$ ligand in 1 by organic acetylides other than $\mathrm{C} \equiv \mathrm{CFc}$, the respective signal of $\mathrm{TiCH}_{2} \mathrm{Si}$ is shifted to lower field while the ${ }^{13} \mathrm{C}\left\{{ }^{1} \mathrm{H}\right\}$-NMR spectrum of 7 shows this signal displaced slightly to higher field. The resonance signals of the acetylenic carbon atoms, which for free acetylenes are normally found between 80 and $100 \mathrm{ppm}$ [17], are strongly shifted to lower field. In the ${ }^{13} \mathrm{C}\left\{{ }^{1} \mathrm{H}\right\}$-NMR spectra of complexes $\mathbf{2}-\mathbf{8}$, the respective signals for $\mathrm{TiC} \equiv \mathrm{C}$ are found between 140 and $165 \mathrm{ppm}$ while the signals for $\mathrm{TiC} \equiv C$ can be found around $125 \mathrm{ppm}$ (Table 1). Similar observations of strong shifts to lower field of these carbon signals were made for bis(alkynyl) titanocene and alkynyl titanocene monochlorides. In these cases, the $\mathrm{Ti}$ centred acetylenic carbon atoms $\mathrm{Ti} C \equiv$ have been found to exhibit resonance signals between 145 and $173 \mathrm{ppm}$ [15]. This contrasts the shifts of the resonance signals of, e.g. $\mathrm{Ti}=\mathrm{CR}_{2}$, which were found between 260 and $360 \mathrm{ppm}$ [18]. Therefore, a double bond character of the Ti acetylide $\sigma$-bond can be excluded.

By cooling a pentane solution of $\{\mathrm{Ti}\} \mathrm{C} \equiv \mathrm{CSiMe}_{3}$ (2) to $-40^{\circ} \mathrm{C}$, yellow crystals have been obtained which were suitable for a X-ray structural determination. The solid state structure of the prototypical Ti acetylide $\mathbf{2}$ is given in Fig. 1. Significant structural details are listed in Table 2. However, the earlier synthesised, analogous titanocene complex $\left(\eta^{5}-\mathrm{C}_{5} \mathrm{H}_{4} \mathrm{SiMe}_{3}\right)_{2} \mathrm{Ti}\left(\mathrm{CH}_{2} \mathrm{SiMe}_{3}\right)$ $\left(\mathrm{C} \equiv \mathrm{CSiMe}_{3}\right)$ was obtained as a yellow oil [19].

Complex 2 crystallises in the monoclinic space group $P 2_{1} / n$ with one independent molecule per unit cell. A comparison of the data obtained for 2 to that of $\{\mathrm{Ti}\} \mathrm{Cl}$ (1) $[11,20]$ reveals that the bond lengths and angles of the $\{\mathrm{Ti}\}$ fragment are virtually unchanged [20]. However, the main structural features of $\mathbf{2}$ appear to combine the structural results obtained for alkynyl and alkyl titanocene derivatives. The $\mathrm{Ti}-\mathrm{C}(\mathrm{sp})$ distance, i.e. $\mathrm{Ti}(1)-\mathrm{C}(1)$ [2.120(4) $\AA$ ], as expected, is significantly shorter than $\mathrm{Ti}-\mathrm{C}\left(\mathrm{sp}^{3}\right)$ bond lengths, e.g. in $\left(\eta^{5}-\right.$ $\left.\mathrm{C}_{5} \mathrm{H}_{5}\right)_{2} \mathrm{TiMe}_{2}$ [2.181(2) and 2.170(2) $\AA$ ] [21], $\left(\eta^{5}-\right.$ $\left.\mathrm{C}_{5} \mathrm{H}_{5}\right)_{2} \mathrm{Ti}\left(\mathrm{CH}_{2} \mathrm{Ph}\right)_{2}$ [2.239(6) and 2.210(5) $\AA$ ] [22] or the one of $\operatorname{Ti}(1)-\mathrm{C}(6)[2.166(4) \AA]$ in molecule 2 . It resembles rather separations found in, for example, the monoalkynyl titanocene $\left[\left(\mathrm{Me}_{2} \mathrm{Si}\right)_{2}\left(\eta^{5}-\mathrm{C}_{5} \mathrm{H}_{2} \mathrm{SiMe}_{3}\right)_{2}\right]-$ $\mathrm{TiCl}\left(\mathrm{C} \equiv \mathrm{CSiMe}_{3}\right)$ [2.10(2) $\left.\mathrm{A}\right]$ [19]. The $\mathrm{C}(1)-\mathrm{C}(2)$ separation of 1.222(5) $\AA$ resembles values of organic or organometallic $\mathrm{C} \equiv \mathrm{C}$ distances [17]. The $\mathrm{C}(2)-\mathrm{Si}(1)$ and $\mathrm{C}(6)-\mathrm{Si}(2)$ bond lengths of $1.831(4)$ and $1.869(4) \AA$,

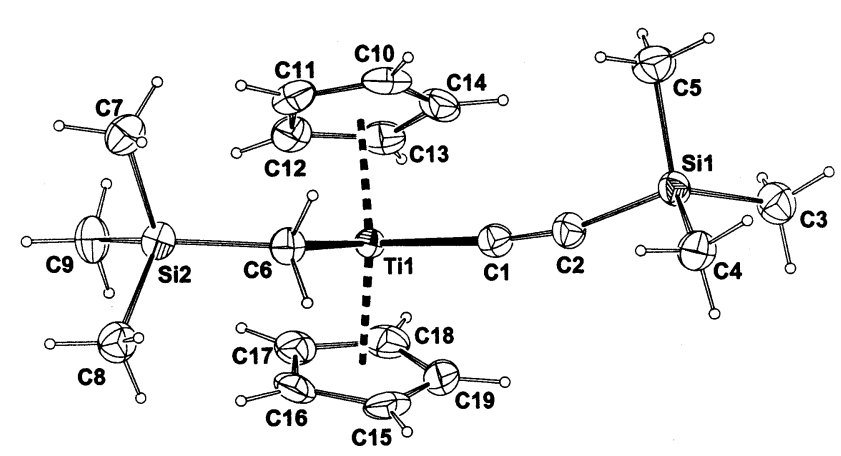

Fig. 1. ORTEP drawing (50\% probability level) of 2 with molecular geometry and atom numbering scheme. 
Table 2

Selected bond lenghts $(\AA)$ and angles $\left(^{\circ}\right)$ for $\mathbf{2}$

\begin{tabular}{lcll}
\hline $\mathrm{Ti}(1)-\mathrm{C}(1)$ & $2.120(4)$ & $\mathrm{Si}(1)-\mathrm{C}(2)$ & $1.831(4)$ \\
$\operatorname{Ti}(1)-\mathrm{C}(6)$ & $2.166(4)$ & $\mathrm{Si}(2)-\mathrm{C}(6)$ & $1.869(4)$ \\
$\mathrm{Ti}(1)-\mathrm{D}(1)^{\mathrm{a}}$ & $2.0793(7)$ & $\mathrm{C}(1)-\mathrm{C}(2)$ & $1.222(5)$ \\
& & & \\
$\operatorname{Ti}(1)-\mathrm{D}(2)^{\mathrm{a}}$ & $2.0749(7)$ & \\
& & & $167.2(4)$ \\
$\mathrm{C}(1)-\mathrm{Ti}(1)-\mathrm{C}(2)$ & $94.68(15)$ & $\mathrm{C}(1)-\mathrm{C}(2)-\mathrm{Si}(1)$ & $129.2(2)$ \\
$\mathrm{D}(1)-\mathrm{Ti}(1)-\mathrm{D}(2)$ & $134.80(4)$ & $\mathrm{Si}(2)-\mathrm{C}(6)-\mathrm{Ti}(1)$ & \\
$\mathrm{C}(2)-\mathrm{C}(1)-\mathrm{Ti}(1)$ & $174.0(4)$ & & \\
\hline
\end{tabular}

${ }^{a} \mathrm{D}(1), \mathrm{D}(2)$ : centroids of the cyclopentadienyl ligands.

respectively, are typical values for carbon-silicon distances in organic or organometallic compounds [23].

The angle enclosed by the $\sigma$-bound organic ligands $\left[\mathrm{C}(1)-\mathrm{Ti}(1)-\mathrm{C}(6) \quad 94.68(15)^{\circ}\right]$ is significantly smaller than these angles found in, for example, bis(alkynyl)titanocenes (around $100^{\circ}$ ) [15] but resembles values obtained for titanocene dichloride derivatives [24]. The angles $\mathrm{C}(2)-\mathrm{C}(1)-\mathrm{Ti}(1)\left[174.0(4)^{\circ}\right]$ and $\mathrm{C}(1)-$ $\mathrm{C}(2)-\mathrm{Si}(1)\left[167.2(4)^{\circ}\right]$ exhibit a somewhat stronger deviation from linearity as compared with the monoacetylide complex $\left[\left(\mathrm{Me}_{2} \mathrm{Si}\right)_{2}\left(\eta^{5}-\mathrm{C}_{5} \mathrm{H}_{2} \mathrm{SiMe}_{3}\right)_{2}\right]-$ $\mathrm{TiCl}\left(\mathrm{C} \equiv \mathrm{CSiMe}_{3}\right)\left[\mathrm{Ti}-\mathrm{C}-\mathrm{C}: 176(1)^{\circ} ; \mathrm{C}-\mathrm{C}-\mathrm{Si}: 174(1)^{\circ}\right]$ [19]. The angle $\mathrm{Si}(2)-\mathrm{C}(6)-\mathrm{Ti}(1)\left[129.2(2)^{\circ}\right]$ is clearly less deviated from the ideal tetrahedral angle as compared with this angle $\left[136.9(1)^{\circ}\right]$ in $\left[\left(\eta^{5}-\right.\right.$ $\left.\mathrm{C}_{5} \mathrm{H}_{5}\right)_{2} \mathrm{TiCl}\left(\mathrm{CH}_{2} \mathrm{SiMe}_{3}\right)$ ] (1) [20]. This means that the incoming $\mathrm{C} \equiv \mathrm{CSiMe}_{3}$ unit modifies the electronic system of the $\{\mathrm{Ti}\}$ fragment in such a way that a proposed hyperconjugation in the $\mathrm{TiCH}_{2} \mathrm{SiMe}_{3}$ fragment is less favoured [20].

The solid state structure of $\mathbf{2}$ clearly shows that the desired 1D array is present. Therefore, the formal substitution of $\mathrm{SiMe}_{3}$ by other ligands should give rise to similar linear arrangements.

\subsection{Reactions of $\{\mathrm{Ti}\} \mathrm{C} \equiv \mathrm{CSiMe}_{3}$ (2) with $\mathrm{Cu}(\mathrm{I})$ compounds}

The coordination chemistry of mono- and bis(alkynyl) titanocene derivatives has been thoroughly investigated and a number of stable mixed-metal compounds have been prepared, e.g. with $\mathrm{Cu}(\mathrm{I})$ compounds $[12,15]$. This led to the formation of heterobimetallic assemblies such as in compounds A [25] or B [26].

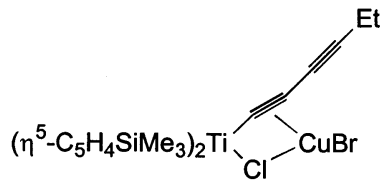

A

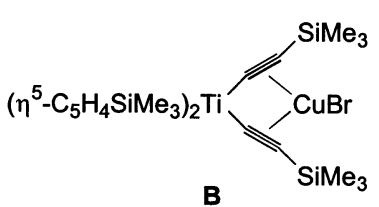

In contrast, the monoalkynyl titanocene compound $\mathbf{2}$ lacks this chelating effect. Consequently, for $\mathbf{2}$ is expected a coordinative behaviour that is comparable to that of organic alkynes or metal acetylides [10a,27]. A mechanism of the complexation reaction of the monoand bis(alkynyl) compounds $\mathbf{A}$ and $\mathbf{B}$ has been suggested earlier, in particular for the reaction of $\left(\eta^{5}\right.$ $\left.\mathrm{C}_{5} \mathrm{H}_{4} \mathrm{SiMe}_{3}\right)_{2} \mathrm{Ti}\left(\mathrm{CH}_{2} \mathrm{SiMe}_{3}\right)\left(\mathrm{C} \equiv \mathrm{CSiMe}_{3}\right)$ with $[\mathrm{CuCl}]_{n}$ [19]. The latter case showed that scrambling of the $\sigma$-bonded groups occurred, leading finally to the formation of stable $\left[\left(\eta^{5}-\mathrm{C}_{5} \mathrm{H}_{4} \mathrm{SiMe}_{3}\right)_{2} \mathrm{Ti}\left(\mathrm{C} \equiv \mathrm{CSiMe}_{3}\right)_{2}\right] \mathrm{CuCl}$ (cf. B), $\left(\eta^{5}-\mathrm{C}_{5} \mathrm{H}_{4} \mathrm{SiMe}_{3}\right)_{2} \mathrm{Ti}\left(\mathrm{CH}_{2} \mathrm{SiMe}_{3}\right) \mathrm{Cl}$ and $\left[\mathrm{CuCH}_{2} \mathrm{SiMe}_{3}\right]_{4}$. In order to further study these reactions and to investigate the use of the $\mathrm{C} \equiv \mathrm{C}$ unit in mono-(alkynyl) $\mathrm{Ti}$ derivatives for the synthesis of heterometallic molecules, compound $\mathbf{2}$ has been reacted with either $[\mathrm{CuCl}]_{n} \quad(1: 1$ molar ratio $)$ or $\left[\mathrm{Cu}(\mathrm{NCMe})_{4}\right]\left[\mathrm{BF}_{4}\right](2: 1$ molar ratio), respectively. These $\mathrm{Cu}(\mathrm{I})$ salts have been chosen because of their wellknown reactivity towards $\mathrm{C} \equiv \mathrm{C}$ triple bonds [12].

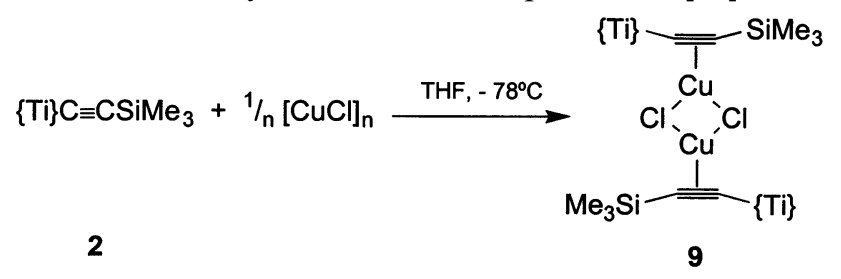

The reaction of 2 with $[\mathrm{CuCl}]_{n}$ in THF $\left(-78^{\circ} \mathrm{C}\right)$ (Eq. 2) led to a colour change from orange to red after $10 \mathrm{~min}$. The course of the reaction was monitored via IR spectroscopy. With the red colour intensifying, the appearance of a band at $1920 \mathrm{~cm}^{-1}\left(v_{\mathrm{C}=\mathrm{C}}\right)$ was detected while the band at $2018 \mathrm{~cm}^{-1}\left(v_{\mathrm{C}=\mathrm{C}}\right.$ of 2 ) lost intensity. This new band is assigned to the absorption band arising from $\eta^{2}$-coordination of the $\mathrm{C} \equiv \mathrm{C}$ fragment to $\mathrm{Cu}(\mathrm{I})$, i.e. to the formation of $\mathbf{9}$. From literature reports, a number of acetylene complexes with $\mathrm{Cu}_{2} \mathrm{Cl}_{2}$ bridging units are known $[12,28]$, inter alia, $\left[\left\{\eta^{2}-\left(\eta^{5}-\right.\right.\right.$ $\left.\left.\left.\mathrm{C}_{5} \mathrm{H}_{5}\right) \mathrm{Fe}(\mathrm{CO})_{2}(\mathrm{C} \equiv \mathrm{CPh})\right\}_{2} \mathrm{Cu}_{2} \mathrm{Cl}_{2}\right][29 \mathrm{a}]$ or the $\left[(\mathrm{CO})_{5} \mathrm{Re}\right]$ containing acetylides by Beck et al. [29b,c]. From the same experiment on laboratory scale, again starting at $-78{ }^{\circ} \mathrm{C}$, it appeared that on rising the temperature a precipitate begins to appear which was gradually formed, and subsequently identified as $\left[\mathrm{CuC} \equiv \mathrm{CSiMe}_{3}\right]_{n}$ (10) [30]. After filtration of the reaction mixture through a pad of Celite, ${ }^{1} \mathrm{H}-\mathrm{NMR}$ spectroscopy of the filtrate showed that the Ti monochloride $\{\mathrm{Ti}\} \mathrm{Cl}(\mathbf{1}) \mathrm{had}$ been formed. From a second experiment conducted exclusively at $-78^{\circ} \mathrm{C}$, an orange solid could be isolated. The IR spectrum of this solid contained again an intensive absorption band at $1920 \mathrm{~cm}^{-1}$, together with $v_{\mathrm{C} \equiv \mathrm{C}}$ of 10. As the ${ }^{1} \mathrm{H}-\mathrm{NMR}$ spectrum of a solution of the yellow solid in THF- $d_{8}$ at $-78^{\circ} \mathrm{C}$ revealed broad singlets at virtually the same resonance frequencies as for $\mathbf{2}$, assignment of the resonance pattern was not 


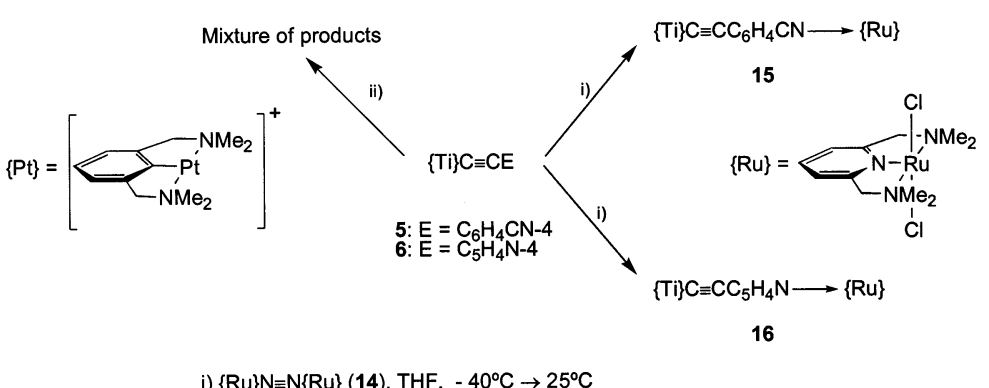

ii) $\left[\{\mathrm{Pt}\} \cdot \mathrm{H}_{2} \mathrm{O}\right]\left[\mathrm{BF}_{4}\right](12)$ or $[\{\mathrm{Pt}\} \cdot \mathrm{NCMe}][\mathrm{OTf}](13), \mathrm{THF},-40^{\circ} \mathrm{C} \rightarrow 25^{\circ} \mathrm{C}$

Scheme 1.

possible. However, a strong indication for the presence of 9 was obtained from FAB MS investigations. The spectra revealed peaks at $m / z 922$ and 425 with the correct isotope patterns which can be assigned to the molecular ion peak of $\mathbf{9}$ and the fragmentation ion $\left[\left(\{\mathrm{Ti}\} \mathrm{C} \equiv \mathrm{CSiMe}_{3}\right) \mathrm{Cu}\right]^{+}$, respectively. Complex 9 is thermally unstable and decomposes rapidly in solution at elevated temperatures while in the solid state it can be handled for only short periods of time. Due to the instability of 9, a satisfactory elemental analysis could not be obtained.

In contrast with the well-defined reaction of $\mathbf{2}$ with $(\mathrm{CuCl})_{n}$, the reaction of 2 with $\left[\mathrm{Cu}(\mathrm{NCMe})_{4}\right]\left[\mathrm{BF}_{4}\right]$ in THF $\left(-78^{\circ} \mathrm{C}\right)$ led solely to the formation of an intractable mixture of reaction products. After evaporation of all volatile material and subsequent work-up at low temperature, IR spectroscopy revealed the absence of a band in the typical region of $v_{\mathrm{CN}}\left(2200-2300 \mathrm{~cm}^{-1}\right)$ [32]. Furthermore, no evidence for $\eta^{2}$-coordination of the $\mathrm{C} \equiv \mathrm{C}$ bond to $\mathrm{Cu}(\mathrm{I})$ was obtained neither from IR nor from ${ }^{1} \mathrm{H}-\mathrm{NMR}\left(\mathrm{CH}_{2} \mathrm{Cl}_{2},-78^{\circ} \mathrm{C}\right)$ spectra of the resulting yellow residue.

These reactions of 2 with $\mathrm{Cu}(\mathrm{I})$ salts indicate that $\eta^{2}$-coordination of the $\mathrm{C} \equiv \mathrm{C}$ unit to $\mathrm{Cu}(\mathrm{I})$ occurs, but that the resulting intermediates are prone to rapid ligand exchange reactions. These results corroborate the earlier results for the reaction of $\left[\left(\eta^{5}-\right.\right.$ $\left.\left.\mathrm{C}_{5} \mathrm{H}_{4} \mathrm{SiMe}_{3}\right)_{2} \mathrm{Ti}\left(\mathrm{CH}_{2} \mathrm{SiMe}_{3}\right)\left(\mathrm{C} \equiv \mathrm{CSiMe}_{3}\right)\right]$ with $[\mathrm{CuCl}]_{n}$ [31]. However, in the case of $\left[\left(\eta^{5}-\right.\right.$ $\left.\left.\mathrm{C}_{5} \mathrm{H}_{5}\right)_{2} \mathrm{Ti}\left(\mathrm{CH}_{2} \mathrm{SiMe}_{3}\right)\left(\mathrm{C} \equiv \mathrm{CSiMe}_{3}\right)\right], \quad 2$, it is solely $\mathrm{Ti}-$ $\mathrm{C}$ (acetylide) $\sigma$-bond cleavage that is observed. The obvious difference with the reaction discussed above is the absence of $\mathrm{SiMe}_{3}$ substituent on the cyclopentadienyl ligands in complex 2.

Apparently, also the anion is important, as in the case of $[\mathrm{CuCl}]_{n}$ a selective formation of $\{\mathrm{Ti}\} \mathrm{Cl}$ (1) and $\left[\mathrm{CuC} \equiv \mathrm{CSiMe}_{3}\right]_{n}(\mathbf{1 0})$ is observed. A comparable influence of the anion on the exchange behaviour of the alkynyl groups between the $\mathrm{Pt}(\mathrm{II})-$ alkynyl compound $\{\mathrm{Pt}\} \mathrm{C} \equiv \mathrm{CSiMe}_{3} \quad\left(\{\mathrm{Pt}\}=\left[\left(\eta^{3}-\mathrm{NCN}\right) \mathrm{Pt}\right]^{+} ; \quad \mathrm{NCN}=\right.$ $\left.\left[\mathrm{C}_{6} \mathrm{H}_{3}\left(\mathrm{CH}_{2} \mathrm{NMe}_{2}\right)_{2}-2,6\right]^{-}\right)$and $\mathrm{Cu}(\mathrm{I})$-salts has been observed. The reaction of this mono-alkynyl metal compound with $[\mathrm{CuCl}]_{n}$ led to the selective formation of
$\{\mathrm{Pt}\} \mathrm{Cl}$ and $\left[\mathrm{CuC} \equiv \mathrm{CSiMe}_{3}\right]_{n}$ (10) via prior formation of an intermediate with $\eta^{2}$-alkynyl-to- $\mathrm{Cu}(\mathrm{I})$ coordination [33].

\subsection{Redox stability of $\{\mathrm{Ti}\} \mathrm{C} \equiv \mathrm{CFc}$ (7)}

Compound 7 is comprised of a molecule in which a reducible group, $\{\mathrm{Ti}\}$, and an oxidisable group, $\mathrm{Fc}$ (ferrocenyl), are connected via a unit which allows electronic communication. Therefore, it was of interest to investigate how this arrangement would influence the redox behaviour of these two fragments. In general, reduction of titanocene derivatives is readily achieved by their reaction with activated $\mathrm{Mg}$ metal [34]. However, 7 remains unchanged in the presence of activated $\mathrm{Mg}$ metal, even after prolonged stirring $\left(\mathrm{THF}, 25^{\circ} \mathrm{C}\right)$ and can be recovered quantitatively from the reaction mixture. Thus, the reducing power of $\mathrm{Mg}$ is not sufficient to add a single electron to the Ti(IV) centre of complex 7 . The change to a stronger reducing agent such as $\mathrm{Na}$ (THF, $0^{\circ} \mathrm{C}$ ) led to the formation of a complex mixture of products which could not be identified (IR, NMR). Similarly, reaction of 7 with $\mathrm{Ag}\left[\mathrm{BF}_{4}\right]\left(\mathrm{THF}, 0^{\circ} \mathrm{C}\right)$ in an attempt to oxidise the $\mathrm{Fe}(\mathrm{II})$ centre gave a mixture of products. Extraction of this mixture (pentane, THF) gave a pentane solution of $\mathrm{HC} \equiv \mathrm{CFc}$ (11) and a $\mathrm{THF}$ solution containing a green compound, which could not identified unequivocally. Thus, compound $\mathbf{7}$ is neither stable to chemical reduction nor to oxidation [8].

\subsection{Reactivity of $\mathbf{5}$ and $\mathbf{6}$ towards late transition metal complexes}

Another strategy to obtain 'early-late' heterometallic compounds is the reaction of suitable late TM complexes with the $N$-ligating site of compounds 5 or $\mathbf{6}$. Therefore, these molecules were reacted with the cationic $\mathrm{Pt}$ complexes $\left[\{\mathrm{Pt}\} \cdot \mathrm{H}_{2} \mathrm{O}\right]\left[\mathrm{BF}_{4}\right] \quad$ (12) and $[\{\mathrm{Pt}\} \cdot \mathrm{NCMe}][\mathrm{OTf}](\mathbf{1 3}$, see Scheme 1) [35] as well as with the neutral dinitrogen bridged Ru complex 14 [36]. Here, the $\mathrm{Ti}$ acetylide could act as an $\eta^{1}$-coordinated ligand after displacement of $\mathrm{H}_{2} \mathrm{O}, \mathrm{MeCN}$ or $\mathrm{N}_{2}$, respectively (Scheme 1). 
Reaction of $\mathbf{5}$ or $\mathbf{6}$, respectively, with the cationic $\mathrm{Pt}$ complexes $\mathbf{1 2}$ or $\mathbf{1 3}$ in the temperature range $-40 \rightarrow$ $25^{\circ} \mathrm{C}$ led to the formation of a mixture of compounds. After concentration of the reaction mixtures, a yellow and poorly soluble residue remained. Further purification of this residue was not successful. These results mirror the behaviour of 2 against $\left[\mathrm{Cu}(\mathrm{NCMe})_{4}\right]\left[\mathrm{BF}_{4}\right]$ (see above).

Nevertheless, well-defined early-late heterobimetallic compounds were obtained when either $\mathbf{5}$ or $\mathbf{6}$ are reacted with $\{\mathrm{Ru}\} \mathrm{N} \equiv \mathrm{N}\{\mathrm{Ru}\}$ (14), yielding the $\mathrm{Ti}-\mathrm{Ru}$ compounds $\mathbf{1 5}$ or $\mathbf{1 6}$, respectively (Scheme 1). The course of the reaction can be followed visually by a colour change of the reaction mixture from brown to an intensive violet. The pure compounds are dark red colored solids. The FAB mass spectra of $\mathbf{1 5}$ and $\mathbf{1 6}$ exhibit a peak for the molecular ion $[\mathrm{M}]^{+}$at the calculated $m / z$ values as well as the expected fragmentation patterns (i.e. $m / z$ at 329: $[\{\mathrm{Ru}\}-\mathrm{Cl}]^{+} ; 295$ : $[\{\mathrm{Ru}\}-$ $2 \mathrm{Cl}]^{+}$). In the IR spectrum of $15, v_{\mathrm{CN}}$ appears at 2197 $\mathrm{cm}^{-1}$. In the coordination chemistry of nitriles, this is a rather unusual shift [32] which points to $\mathrm{C} \equiv \mathrm{N}$ bond weakening due to the backbonding properties of the coordinated $\{\mathrm{Ru}\}$ fragment. This displacement to lower wavenumbers is also observed with $\{\mathrm{Ru}\} \mathrm{NCPh}(\mathbf{1 7}$, $v_{\mathrm{CN}}: 2214 \mathrm{~cm}^{-1}$ ) but for this compound is not as strong as with 15. This indicates a significant influence of the titanocene fragment on the electronic properties of the nitrile system present in $\mathbf{1 5}$. The ${ }^{1} \mathrm{H}-\mathrm{NMR}$ spectra of $\mathbf{1 5}$ and 16 in $\mathrm{CDCl}_{3}$ consist of sharp and well resolved signals. The absence of an $\mathrm{AB}$ pattern for the $\mathrm{CH}_{2} \mathrm{NMe}_{2}$ protons indicates that the coordination of 5 or 6 to $\{\mathrm{Ru}\}$ gives rise to an apparent molecular symmetry plane containing the $\mathrm{C}$ - and $\mathrm{N}$-centres of the $-\mathrm{CH}_{2} \mathrm{NMe}_{2}$ ortho-substituents, i.e. that a linear arrangement of the metal centres is obtained.

\subsection{Electrochemical behaviour}

A number of representative mono- and bimetallic Ti acetylides have been subjected to cyclovoltammetric investigation. The objectives of this work were to study the influence of both the nature of the organic groups and the effect of the proximity of a second metal atom on the $\mathrm{Ti}(\mathrm{IV}) / \mathrm{Ti}(\mathrm{III})$ redox properties and, indirectly, the role of connecting the metal centers. Table 3 depicts the cyclovoltammetric data of representative examples and, for comparative purposes, the data of both $\left(\eta^{5}\right.$ $\left.\mathrm{C}_{5} \mathrm{H}_{5}\right)_{2} \mathrm{TiCl}_{2}$ [37] and $\left[\left(\eta^{5}-\mathrm{C}_{5} \mathrm{H}_{5}\right)_{2} \mathrm{TiCl}\left(\mathrm{CH}_{2} \mathrm{SiMe}_{3}\right)\right]$ (1) have been included.

The cyclic voltammogram of neat $\left(\eta^{5}-\mathrm{C}_{5} \mathrm{H}_{5}\right)_{2} \mathrm{TiCl}_{2}$ exhibits a (chemically) reversible reductive process at $E_{1 / 2}=-1.45 \mathrm{~V}(\Delta E=190 \mathrm{mV})$ which can be assigned to the $\mathrm{Ti}(\mathrm{III}) / \mathrm{Ti}(\mathrm{IV})$ redox couple [37]. This behaviour contrasts results obtained in acetonitrile solution, where this process has been shown to be irreversible [9].
Interestingly, the blocking of one reactive site with a $\sigma$-bonded neosilyl group as in $\{\mathrm{Ti}\} \mathrm{Cl}$ (1) leads to the observation of an irreversible reductive process at $E_{\text {red }}=-1.85 \mathrm{~V}$. Nevertheless, compared with $\left(\eta^{5}\right.$ $\left.\mathrm{C}_{5} \mathrm{H}_{5}\right)_{2} \mathrm{TiCl}_{2}$ the reduction of $\mathrm{Ti}(\mathrm{IV})$ to $\mathrm{Ti}(\mathrm{III})$ in compound $\mathbf{1}$ is shifted by ca. $0.4 \mathrm{~V}$ to a more negative potential. When the chloride ligand of $\mathbf{1}$ is substituted by either $\mathrm{C} \equiv \mathrm{CSiMe}_{3}$ (compound 2) or $\mathrm{C} \equiv \mathrm{CFc}$ (compound 7), the cyclic voltammogram reveals again a reversible reduction wave for the $\mathrm{Ti}(\mathrm{III}) / \mathrm{Ti}(\mathrm{IV})$ couple [2: $E_{1 / 2}=-2.26 \mathrm{~V}(\Delta E=100 \mathrm{mV}) ; 7: E_{1 / 2}=-2.25 \mathrm{~V}$ $(\Delta E=70 \mathrm{mV})]$ which is again shifted by ca. $0.4 \mathrm{~V}$ to a more negative potential. Upon substitution of the acetylide bridge with aromatic units, as in compounds 3 or $\mathbf{6}$, the shift induced by the second substitution is not as large as for $\mathbf{2}$ or $\mathbf{7}$ (as compared with the $E_{1 / 2}$ of $\mathbf{1}$ ). As can be observed from Table 3, the cyclic voltammogram of 3 exhibits the reversible reduction of Ti(IV) at $E_{1 / 2}=-2.08 \mathrm{~V}(\Delta E=70 \mathrm{mV})$ and for compound $\mathbf{6}$ at $E_{1 / 2}=-1.97 \mathrm{~V}(\Delta E=100 \mathrm{mV})$. With compound 2 taken as standard, this can be interpreted by means of the aromatic system in $\mathrm{C}_{6} \mathrm{H}_{3}\left(\mathrm{CH}_{2} \mathrm{NMe}_{2}\right)_{2}-3,5$ being a weak and the electron poor aromatic system $\mathrm{C}_{5} \mathrm{H}_{4} \mathrm{~N}-4$ (compound 6) as being a stronger electron withdrawing group. In total, the stepwise substitution of the two $\mathrm{Cl}$ ligands of $\left(\eta^{5}-\mathrm{C}_{5} \mathrm{H}_{5}\right)_{2} \mathrm{TiCl}_{2}$ by $\sigma$-bonded organic ligands leads to an increase in electron density of the Ti core, which manifests itself in the large shift (by almost $1 \mathrm{~V}$ ) of $E_{1 / 2}$ to a more negative potential. The formal substitution of $\mathrm{SiMe}_{3}$ in $\mathbf{2}$ by a ferrocenyl group (compound 7) does not affect the value of the reversible reductive process. This contrasts results which have been obtained with ferrocenyl-substituted bis(alkynyl) ti-

Table 3

Comparison of electrochemical data for $\left(\eta^{5}-\mathrm{C}_{5} \mathrm{H}_{5}\right)_{2} \mathrm{TiCl}_{2}$ and compounds $1-3,6-8$ and $15-17$

\begin{tabular}{|c|c|c|c|c|}
\hline \multirow[t]{2}{*}{ Compound } & \multicolumn{2}{|c|}{ Reduction } & \multicolumn{2}{|c|}{ Oxidation } \\
\hline & $E_{1 / 2}(\mathrm{~V})$ & $\Delta E(\mathrm{mV})$ & $E_{1 / 2}(\mathrm{~V})$ & $\Delta E(\mathrm{mV})$ \\
\hline $\begin{array}{l}\left(\eta^{5}-\mathrm{C}_{5} \mathrm{H}_{5}\right)_{2} \mathrm{TiCl}_{2} \\
\mathbf{1}\end{array}$ & $\begin{array}{l}-1.45 \\
-1.85^{\mathrm{a}}\end{array}$ & 190 & & \\
\hline 2 & -2.26 & 100 & & \\
\hline 3 & -2.08 & 70 & & \\
\hline 6 & -1.97 & 100 & & \\
\hline 7 & -2.25 & 70 & $-0.08^{\mathrm{b}}$ & \\
\hline 8 & -2.12 & 100 & & \\
\hline 15 & -2.15 & 60 & -0.42 & 90 \\
\hline 16 & -1.98 & 80 & -0.46 & 100 \\
\hline 17 & & & -0.32 & 70 \\
\hline
\end{tabular}

\footnotetext{
${ }^{\text {a }}$ Irreversible reductive process.

${ }^{\mathrm{b}}$ Irreversible oxidative process and immediately appearance of a reversible wave at $E_{1 / 2}=0.01 \mathrm{~V}, \Delta E=130 \mathrm{mV}$ (10). The cyclic voltammograms have been recorded at $c=1 \times 10^{-3} \mathrm{M}$ in a THF solution in the presence of $\left[n-\mathrm{Bu}_{4} \mathrm{~N}\right]\left[\mathrm{PF}_{6}\right](c=0.1 \mathrm{M})$ at $25^{\circ} \mathrm{C}$ under $\mathrm{N}_{2}$; scan-rate $100 \mathrm{mV} \mathrm{s}^{-1}$; potentials are referenced to $\mathrm{FcH} / \mathrm{FcH}^{+}$ $\left(E_{1 / 2}=0.00 \mathrm{~V}\right)$.
} 
tanocenes, where an additional shift to more negative potentials was observed ([7]c, [9]). In the homo-bimetallic compound $\left[\{\mathrm{Ti}\} \mathrm{C} \equiv \mathrm{CC}_{6} \mathrm{H}_{4} \mathrm{C} \equiv \mathrm{C}\{\mathrm{Ti}\}\right], 8$, one could predict that the presence of two metal centres that are connected by a conjugated $\pi$-system would lead to the appearance of two distinct reduction waves. However, this is not the case. As shown in Table 3, both titanocene fragments have the same reversible reduction potential, which manifests itself in a concerted two-electron process at $E_{1 / 2}=-2.12 \mathrm{~V}(\Delta E=100 \mathrm{mV})$. An explanation can be given by the fact that the intermetallic distance imposed by the 1,4-di(ethynyl)benzene fragment is too large and therefore, despite the presence of a conjugated $\pi$-system, the two metals are electrochemically isolated from each other [38]. The Ti(III)/Ti(IV) redox potential of the mixed-metal complexes $15\left[E_{1 / 2}\right.$ $=-2.15 \mathrm{~V}(\Delta E=60 \mathrm{mV})]$ and $16\left[E_{1 / 2}=-1.98 \mathrm{~V}\right.$ $(\Delta E=80 \mathrm{mV})]$ indicate that the $\eta^{1}$-coordinated $\mathrm{Ru}$ complex fragment $\{\mathrm{Ru}\}$ does not add electrochemically relevant additional electron density on the Ti(IV) centre. This fact has already been observed with compound 7. This interpretation is supported by a comparison of the $\mathrm{Ti}(\mathrm{III}) / \mathrm{Ti}(\mathrm{IV})$ redox potentials of $\left[\{\mathrm{Ti}\} \mathrm{C} \equiv \mathrm{CC}_{6} \mathrm{H}_{4} \mathrm{~N}\right.$ 4] 6 and its $\{\mathrm{Ru}\}$-adduct, 16. Both of these data reveal that the concerned reversible Ti redox couples remain virtually unaffected.

As expected, compounds $\mathbf{1}$ and $\mathbf{2}$ do not exhibit oxidation processes under these conditions. The heterobimetallic complex 7 reveals an irreversible one-electron oxidation at $E_{\text {ox }}=-0.08 \mathrm{~V}$. Immediately after this first irreversible oxidative step, a second and then reversible oxidation wave at $E_{1 / 2}=0.01 \mathrm{~V}(\Delta E=130 \mathrm{mV})$ appears. The latter persists in multi cycle experiments. It is also a one-electron process and can be assigned to the ferrocene derivative $\mathrm{HC} \equiv \mathrm{CFc}, \mathbf{1 1}$ (see above), which is formed instantaneously under the conditions of the measurement. Taking into account the observations made for complexes such as $\left(\eta^{5}-\mathrm{C}_{5} \mathrm{H}_{4} \mathrm{SiMe}_{3}\right)_{2}$ $\mathrm{Ti}(\mathrm{C} \equiv \mathrm{CFc})_{2} \quad[7 \mathrm{c}] \quad$ or $\quad\left(\eta^{5}-\mathrm{C}_{5} \mathrm{H}_{4} \mathrm{SiMe}_{3}\right)_{2} \mathrm{Ti}(\mathrm{C} \equiv \mathrm{CC} \equiv \mathrm{CFc})_{2}$ [7b] the conclusion can be drawn that the oxidation of the ferrocenyl unit leads immediately to the cleavage of the $\mathrm{Ti}-\mathrm{C} \equiv \sigma$-bond. By removal of an electron from this bond, the electrochemically generated $\mathrm{Fe}(\mathrm{III})$ centre is then reduced to $\mathrm{Fe}(\mathrm{II})$ via single electron transfer from the $\mathrm{Ti}-\mathrm{C} \equiv \sigma$-bond through the $\mathrm{C}_{2}$ unit and the conjugated $\pi$-system of the $\mathrm{C}_{5} \mathrm{H}_{4}$ ring inducing formation of $\mathrm{HC} \equiv \mathrm{CFc}$ (11). Nevertheless, the $\mathrm{Ru}$ containing complexes 15 and 16 behave differently. As exemplified in Fig. 2 for compound 16, the $\mathrm{Ru}(\mathrm{II}) / \mathrm{Ru}$ (III) oxidation is like the $\mathrm{Ti}(\mathrm{III}) / \mathrm{Ti}(\mathrm{IV})$ redox couple a reversible oneelectron process [15: $E_{1 / 2}=-0.42 \mathrm{~V}(\Delta E=90 \mathrm{mV}) ; 1$ 16: $\left.E_{1 / 2}=-0.46 \mathrm{~V}(\Delta E=100 \mathrm{mV})\right]$. This $\mathrm{Ru}(\mathrm{II}) / \mathrm{Ru}(\mathrm{III})$ redox couple could be assigned unequivocally by comparison with the electrochemical data of the new $\mathrm{Ru}$ benzonitrile complex $\{\mathrm{Ru}\} \mathrm{NCPh}(17)\left[E_{1 / 2}=-0.32 \mathrm{~V}\right.$ $(\Delta E=70 \mathrm{mV})$ ] which exhibits the one-electron oxida-

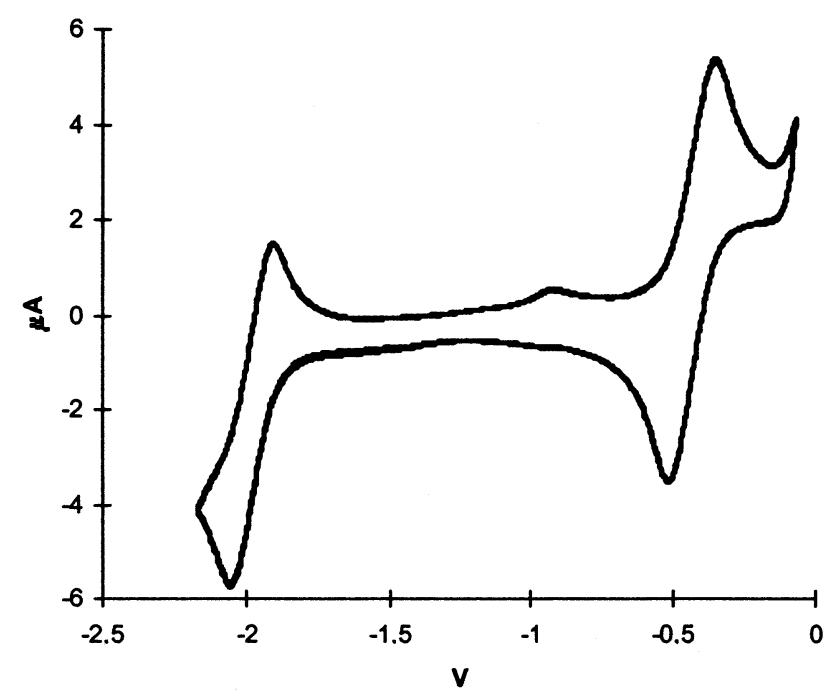

Fig. 2. Cyclic voltammogram of compound $\mathbf{1 6}$ in THF solution in the presence of $\left[n-\mathrm{Bu}_{4} \mathrm{~N}\right]\left[\mathrm{PF}_{6}\right](c=0.1 \mathrm{M})$ at $25^{\circ} \mathrm{C}$ under $\mathrm{N}_{2}$ at a scan rate of $100 \mathrm{mV} \mathrm{s}^{-1}$. Potentials are referenced to $\mathrm{FcH} / \mathrm{FcH}^{+}$as internal standard $\left(E_{1 / 2}=0.00 \mathrm{~V}\right)$.

tion in this range. However, the oxidation potential $\mathrm{Ru}(\mathrm{II}) / \mathrm{Ru}(\mathrm{III})$ is shifted slightly to a more negative value. This indicates that the presence of the $\{\mathrm{Ti}\} \mathrm{C} \equiv \mathrm{C}$ unit in a position para to $\{\mathrm{Ru}\}$ influences the latter in such a way that the oxidation of $\mathrm{Ru}(\mathrm{II})$ to $\mathrm{Ru}(\mathrm{III})$ is facilitated.

\section{Conclusions}

Ti mono-acetylides $\mathbf{2}-\mathbf{8}$ have been prepared and characterised. They have been connected successfully to a second metal centre via the alkynyl system. The X-ray crystal structure of prototypical $\{\mathrm{Ti}\} \mathrm{C} \equiv \mathrm{CSiMe}_{3}$ showed clearly the $1 \mathrm{D}$ arrangement with respect to the $\mathrm{Ti}-$ $\mathrm{C} \equiv \mathrm{C}-\mathrm{R}$ fragment. The $\mathrm{C} \equiv \mathrm{C}$ unit of $\mathbf{2}$ exhibited the expected $\eta^{2}$-coordinative behaviour with $[\mathrm{CuCl}]_{n}$. This led to the formation of $\left[\left(\eta^{2}-\{\mathrm{Ti}\} \mathrm{C} \equiv \mathrm{CSiMe}_{3}\right)_{2} \mathrm{Cu}_{2} \mathrm{Cl}_{2}\right](\mathbf{9})$ at low temperature. However, this complex decomposed at temperatures above $-78^{\circ} \mathrm{C}$ to yield $\{\mathrm{Ti}\} \mathrm{Cl}, \mathbf{1}$, and $\left[\mathrm{CuC} \equiv \mathrm{CSiMe}_{3}\right]_{n}$, exclusively. This is a different behaviour than presented for the system $\left(\eta^{5}\right.$ -

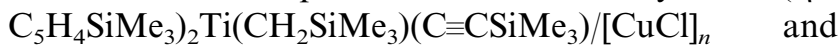
suggests an influence of the type of cyclopentadienyl substituents on the reactivity of the Ti centre. Generally, the reaction of the Ti acetylides presented in this work with cationic complexes leads to the formation of product mixtures, which can not be separated into pure compounds. The behaviour of the $\{\mathrm{Ti}\} \mathrm{C} \equiv \mathrm{CFc}$ complex 7 has been investigated. It reveals that 7 is not stable against chemical oxidation with $\mathrm{Ag}\left[\mathrm{BF}_{4}\right]$ or reduction with $\mathrm{Na}$ metal. However, the use of activated $\mathrm{Mg}$ metal does not lead to a reduction of 7 at all and 7 can be recovered from the reaction mixture. Bimetallic com- 
plexes have been obtained via (i) incorporation of a metal complex fragment into the acetylide (compounds 7 and 8) and (ii) coordination of the appropriate $\mathrm{Ti}$ acetylides, i.e. $\mathbf{5}$ and $\mathbf{6}$, to $\{\mathrm{Ru}\}$ (compounds $\mathbf{1 5}$ and 16). The cyclic voltammetric investigation of representative examples shows an anodic shift of the Ti(III)/ $\mathrm{Ti}(\mathrm{IV})$ redox potential upon substitution of $\mathrm{Cl}$ in $\mathbf{1}$ by $\mathrm{C} \equiv \mathrm{CR}$ groups in compounds $\mathbf{2}-\mathbf{8}$. The size of the shift has been found to be dependent on the electronic properties of the group R. Electron donating groups $\mathrm{R}$ give larger shifts while with electron withdrawing groups such as 4-pyridyl only a small shift is obtained. The incorporation or attachment of a second metal centre (cf. 7, 15 and 16) does not influence the redox behaviour of the Ti centre. However, the oxidation of $\mathrm{Ru}(\mathrm{II})$ to $\mathrm{Ru}(\mathrm{III})$ is facilitated by the presence of the $\{\mathrm{Ti}\}$ unit in the system. This may be due to a lowering of the energy of the transition state of the oxidation of $\mathrm{Ru}(\mathrm{II})$ to $\mathrm{Ru}(\mathrm{III})$. The intensive colours of these earlylate TM complexes indicate that their electronic system is strongly influenced by having joined two distinct metal centres via $\pi$-conjugated groups. Further investigations on these complexes regarding their electronic structure are in progress.

\section{Experimental}

\subsection{General methods}

All reactions were carried out under an atmosphere of dry nitrogen using standard Schlenk techniques. Tetrahydrofuran (THF) and diethyl ether $\left(\mathrm{Et}_{2} \mathrm{O}\right)$ were purified by distillation from sodium/benzophenone ketyl and pentane was purified by distillation from calcium hydride. Infrared spectra were obtained with a Mattson Galaxy Series FTIR 5000. The ${ }^{1} \mathrm{H}$ - and ${ }^{13} \mathrm{C}\left\{{ }^{1} \mathrm{H}\right\}$-NMR spectra were recorded on a Bruker AC 300 spectrometer. Chemical shifts are reported in $\delta$ units (parts per million) downfield from tetramethylsilane with the solvent as the internal reference signal. FAB mass spectra were recorded at the Department of Mass Spectrometry, Bijvoet Center, Utrecht University on a JEOL JMS SX/SX 102A four sector mass spectrometer operating at $10 \mathrm{kV}$ accelerating voltage. Melting points were determined on a Büchi melting point apparatus. Microanalyses were performed by H. Kolbe, Mikroanalytisches Laboratorium, Mülheim/Ruhr, Germany. Electrochemical measurements were carried out by cyclic voltammetry in a solution of $\left[n-\mathrm{Bu}_{4} \mathrm{~N}\right]\left[\mathrm{PF}_{6}\right]$ $(c=0.1 \mathrm{M})$ in $\mathrm{THF}$ at $25^{\circ} \mathrm{C}$, using a standard threeelectrode cell on a Princeton Applied Research EG\&G 263A analyzer. All potentials were referenced to the ferrocene/ferrocenium redox couple which was used as internal reference with $E_{1 / 2}=0.00 \mathrm{~V}$.

\subsection{General remarks}

The starting materials $\{\mathrm{Ti}\} \mathrm{Cl}$ (1) $[11,20], \mathrm{C}_{6} \mathrm{H}_{3}-$ $\left(\mathrm{CH}_{2} \mathrm{NMe}_{2}\right)_{2}-1,3-(\mathrm{C} \equiv \mathrm{CH})-5 \quad$ [39], $\mathrm{IC}_{6} \mathrm{H}_{2}\left(\mathrm{CH}_{2} \mathrm{NMe}_{2}\right)_{2}-$ 2,6-(C $\equiv \mathrm{CH})-4$ [33] $\mathrm{HC} \equiv \mathrm{CC}_{6} \mathrm{H}_{4} \mathrm{CN}-4$ [40], $\mathrm{HC} \equiv \mathrm{CC}_{5} \mathrm{H}_{4}-$ $\mathrm{N}-4 \quad[41], \quad \mathrm{HC} \equiv \mathrm{CFc} \quad[42], \quad\left[\mathrm{Cu}(\mathrm{NCMe})_{4}\right]\left[\mathrm{BF}_{4}\right] \quad[43]$, $\left[\{\mathrm{Pt}\} \cdot \mathrm{H}_{2} \mathrm{O}\right]\left[\mathrm{BF}_{4}\right](\mathbf{1 2})[35],[\{\mathrm{Pt}\} \cdot \mathrm{NCMe}][\mathrm{OTf}](13)$ [35] and $\{\mathrm{Ru}\} \mathrm{N} \equiv \mathrm{N}\{\mathrm{Ru}\}$ (14) [36] were prepared following published procedures. All other chemicals were purchased from commercial sources.

\subsection{Synthesis of $\{T i\} C \equiv \mathrm{CSiMe}_{3}$ (2)}

At $-78^{\circ} \mathrm{C}, 330 \mathrm{mg}(1.2 \mathrm{mmol})$ of 1 were added to a solution of $\mathrm{LiC} \mathrm{CSiMe}_{3}(125 \mathrm{mg}, 1.2 \mathrm{mmol})$ in $\mathrm{Et}_{2} \mathrm{O}$ $(100 \mathrm{ml})$. After stirring $\left(5 \mathrm{~h} ; 25^{\circ} \mathrm{C}\right)$, the reaction mixture was evaporated. The resulting brown residue was then extracted with pentane $(3 \times 20 \mathrm{ml})$ and filtered through a pad of Celite. The obtained orange solution was concentrated to ca. $5 \mathrm{ml}$ and crystallisation at $-20^{\circ} \mathrm{C}$ yielded $2(260 \mathrm{mg}, 70 \%$ based on $\mathbf{1})$ as orange needles.

M.p.: [ $\left.{ }^{\circ} \mathrm{C}\right]$ 96. IR (KBr): $\left[\mathrm{cm}^{-1}\right] 2017$ (s) $\left[v_{\mathrm{C}=\mathrm{C}}\right], 1253$ (s) $\left[v_{\mathrm{CSi}}\right], 1245$ (s) $\left[v_{\mathrm{CSi}}\right] \cdot{ }^{1} \mathrm{H}-\mathrm{NMR}\left(\mathrm{CDCl}_{3}\right):[\delta]-0.05$ (s, $9 \mathrm{H}, \mathrm{Si}_{\mathrm{Me}}$ ), 0.08 (s, $9 \mathrm{H}, \mathrm{SiMe}$ ), 1.60 (s, $2 \mathrm{H}$, $\left.\mathrm{TiCH}_{2}\right), 6.22\left(\mathrm{~s}, 10 \mathrm{H}, \mathrm{C}_{5} H_{5}\right) .{ }^{13} \mathrm{C}\left\{{ }^{1} \mathrm{H}\right\}-\mathrm{NMR}\left(\mathrm{CDCl}_{3}\right)$ :

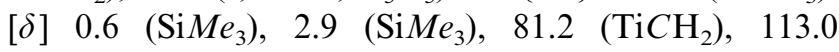
$\left(C_{5} \mathrm{H}_{5}\right), 128.6(\equiv C \mathrm{Si}), 164.6$ ( $\left.\equiv C \mathrm{Ti}\right)$. FAB-MS $[\mathrm{m} / z$ (rel. int.)]: 361 (20) $[\mathrm{M}-\mathrm{H}]^{+}, 347$ (30) $[\mathrm{M}-\mathrm{Me}]^{+}, 275$ (100) $\left[\mathrm{C}_{15} \mathrm{H}_{19} \mathrm{SiTi}\right]^{+}, 178$ (90) $\left[\mathrm{C}_{10} \mathrm{H}_{10} \mathrm{Ti}\right]^{+}, 73$ (20) $\left[\mathrm{C}_{3} \mathrm{H}_{9} \mathrm{Si}\right]^{+}$. Anal. Calc. for $\mathrm{C}_{19} \mathrm{H}_{30} \mathrm{Si}_{2} \mathrm{Ti}$ (362.53): C, 62.95; H, 8.34; Si, 15.50. Found: C, 62.85; H, 8.31; Si, 15.68 .

\subsection{X-ray structure determination of 2}

The structure of $\mathbf{2}$ was determined from single crystal X-ray diffraction, which were collected on a Bruker SMART CCD diffractometer using $\mathrm{Mo}-\mathrm{K}_{\alpha}$ radiation. Crystallographic data of $\mathbf{2}$ are given in Table 4. The structure was solved by direct methods (SHELX 97; G.M. Sheldrick, University of Göttingen: Göttingen, Germany, 1997). An empirical absorption correction was applied. The structure was refined by the leastsquares method based on $F^{2}$ with all reflections. All non-hydrogen atoms were refined anisotropically; the hydrogen atoms were placed in calculated positions.

\subsection{Synthesis of $\{\mathrm{Ti}\} \mathrm{C} \equiv \mathrm{CC}_{6} \mathrm{H}_{3}\left(\mathrm{CH}_{2} \mathrm{NMe}_{2}\right)_{2}-3,5$ (3)}

Experimental conditions and work-up were the same as described for the synthesis of 2. Experimental details: $200 \mathrm{mg}(0.9 \mathrm{mmol}) \quad 1-(\mathrm{LiC} \equiv \mathrm{C})-3,5-\left(\mathrm{Me}_{2} \mathrm{NCH}_{2}\right)_{2} \mathrm{C}_{6} \mathrm{H}_{3}$, $270 \mathrm{mg}$ ( $0.9 \mathrm{mmol})$ 1, $100 \mathrm{ml} \mathrm{Et}{ }_{2} \mathrm{O}$. Yield: $260 \mathrm{mg}, 60 \%$ based on 1. 
M.p.: [ $\left.{ }^{\circ} \mathrm{C}\right]$ 75. IR (KBr): [cm $\left.{ }^{-1}\right] 2069$ (s) [ $\left.v_{\mathrm{C}=\mathrm{C}}\right]$. ${ }^{1} \mathrm{H}-\mathrm{NMR}\left(\mathrm{CDCl}_{3}\right):[\delta]-0.03\left(\mathrm{~s}, 9 \mathrm{H}, \mathrm{Si} \mathrm{Me}_{3}\right), 1.64(\mathrm{~s}$, $\left.2 \mathrm{H}, \mathrm{TiCH}_{2}\right), 2.22(\mathrm{~s}, 12 \mathrm{H}, \mathrm{NMe}), 3.34\left(\mathrm{~s}, 4 \mathrm{H}, \mathrm{CH}_{2}\right)$, $6.27\left(\mathrm{~s}, 10 \mathrm{H}, \mathrm{C}_{5} H_{5}\right), 7.06\left(\mathrm{~s}, 1 \mathrm{H}, \mathrm{C}_{6} H_{3}\right), 7.10(\mathrm{~s}, 2 \mathrm{H}$, $\left.\mathrm{C}_{6} H_{3}\right) \cdot{ }^{13} \mathrm{C}\left\{{ }^{1} \mathrm{H}\right\}-\mathrm{NMR}\left(\mathrm{CDCl}_{3}\right):[\delta] 3.0\left(\mathrm{Si} M e_{3}\right), 45.4$ $(\mathrm{NMe}), 64.2\left(\mathrm{CH}_{2}\right), 81.0\left(\mathrm{TiCH}_{2}\right), 123.9(\mathrm{TiC} \equiv C)$, $125.4\left({ }^{i} \mathrm{C} / \mathrm{C}_{6} \mathrm{H}_{3}\right), 128.3\left(\mathrm{CH} / \mathrm{C}_{6} \mathrm{H}_{3}\right), 130.2\left(\mathrm{CH} / \mathrm{C}_{6} \mathrm{H}_{3}\right)$, $138.7\left({ }^{i} \mathrm{C} / \mathrm{C}_{6} \mathrm{H}_{3}\right), 143.7$ ( $\left.\mathrm{TiC} \equiv \mathrm{C}\right)$. FAB-MS $[\mathrm{m} / z$ (rel. int.)]: 481 (50) $[\mathrm{M}+\mathrm{H}]^{+}, \quad 394$ (40) $[\mathrm{M}+\mathrm{H}]^{+}-$ $\mathrm{C}_{4} \mathrm{H}_{11} \mathrm{Si}, 217$ (20) $\left[\mathrm{C}_{14} \mathrm{H}_{17} \mathrm{~N}_{2}\right]^{+}$. Anal. Calc. for $\mathrm{C}_{28} \mathrm{H}_{40} \mathrm{~N}_{2} \mathrm{SiTi}$ (480.63): C, 69.97; H, 8.39; N, 5.83; Si, 5.88. Found: C, 69.86; H, 8.33; N, 5.95; Si, 5.88.

\subsection{Synthesis of $\{\mathrm{Ti}\} \mathrm{C} \equiv \mathrm{CC}_{6} \mathrm{H}_{2} \mathrm{I}-4-\left(\mathrm{CH}_{2} \mathrm{NMe}_{2}\right)_{2}-3,5$ (4)}

Experimental conditions and work-up were the same as described for the synthesis of 2. Experimental details: $250 \mathrm{mg}(0.7 \mathrm{mmol}) \quad 1-(\mathrm{LiC} \equiv \mathrm{C})-2,6-\left(\mathrm{Me}_{2} \mathrm{NCH}_{2}\right)_{2} \mathrm{C}_{6} \mathrm{H}_{2} \mathrm{I}$,

Table 4

Crystal and intensity collection data for $\mathbf{2}$

\begin{tabular}{|c|c|}
\hline Empirical formula & $\mathrm{C}_{19} \mathrm{H}_{30} \mathrm{Si}_{2} \mathrm{Ti}$ \\
\hline Molecular mass & 362.51 \\
\hline Crystal system & Monoclinic \\
\hline Space group & $P 2_{1} / n$ \\
\hline$a(\AA)$ & $6.6618(1)$ \\
\hline$b(\AA)$ & $21.1906(3)$ \\
\hline$c(\AA)$ & $14.2395(1)$ \\
\hline$\beta\left(^{\circ}\right)$ & $91.360(1)$ \\
\hline$V\left(\AA^{3}\right)$ & $2009.59(4)$ \\
\hline$\rho_{\text {calc }}\left(\mathrm{g} \mathrm{cm}^{-3}\right)$ & 1.198 \\
\hline$F(000)$ & 776 \\
\hline$Z$ & 4 \\
\hline Crystal dimensions (mm) & $0.4 \times 0.04 \times 0.04$ \\
\hline Diffractometer model & Bruker SMART CCD \\
\hline Linear absorption coefficient $\left(\mathrm{mm}^{-1}\right)$ & 0.541 \\
\hline Absorption correction & Empirical using SADABS \\
\hline Max. and min. transmission & 0.927996 and 0.719564 \\
\hline Radiation $(\lambda, \AA)$ & Mo- $\mathrm{K}_{\alpha}(0.71073)$ \\
\hline Temperature $(\mathrm{K})$ & $173(2)$ \\
\hline Scan mode & $\omega$-scan \\
\hline Scan range $\left({ }^{\circ}\right)$ & $1.72<2 \theta<29.07$ \\
\hline Index ranges & $\begin{array}{l}-8 \leq h \leq 8,-27 \leq k \leq 28 \\
-18 \leq l \leq 14\end{array}$ \\
\hline Total reflections & 15026 \\
\hline Unique reflections & 4702 \\
\hline Observed reflections $[I \geq 2 \sigma(I)]$ & 2778 \\
\hline Refinement method & $\begin{array}{l}\text { Full-matrix, least-squares } \\
\left(F^{2}\right)\end{array}$ \\
\hline Refined parameters & 202 \\
\hline$R_{\text {int }}$ & 0.1135 \\
\hline$R_{1}^{\mathrm{a}}, w R_{2}^{\mathrm{a}, \mathrm{b}}[I \geq 2 \sigma(I)]$ & $0.0782,0.1078$ \\
\hline$R_{1}^{\mathrm{a}}, w R_{2}^{\mathrm{a}, \mathrm{b}}$ (all data) & $0.1512,0.1305$ \\
\hline $\mathrm{GOF}(S)^{\mathrm{c}}$ & 1.043 \\
\hline $\begin{array}{l}\text { Max. and min. peaks in final Fourier } \\
\text { map }\left(\mathrm{e} \AA^{-3}\right)\end{array}$ & 0.387 and -0.553 \\
\hline
\end{tabular}

$\left.{ }^{\mathrm{a}} R_{1}=\left[\Sigma\left(|| F_{\mathrm{o}}|-| F_{\mathrm{c}} \mid\right) / \Sigma\left|F_{\mathrm{o}}\right|\right)\right] ; w R_{2}=\left[\Sigma\left(w\left(F_{\mathrm{o}}^{2}-F_{\mathrm{c}}^{2}\right)^{2}\right) / \Sigma\left(w F_{\mathrm{o}}^{4}\right)\right]^{0.5}$.

${ }^{\mathrm{b}} w=1 /\left[s^{2}\left(F_{\mathrm{o}}^{2}\right)+(0.0083 P)^{2}+3.3243 P\right]$ with $P=\left[F_{\mathrm{o}}^{2}+2 F_{\mathrm{c}}^{2}\right] / 3$.

${ }^{\mathrm{c}} S=\left[\Sigma w\left(F_{\mathrm{o}}^{2}-F_{\mathrm{c}}^{2}\right)^{2}\right] /(n-p)^{0.5} ; \quad n=$ number of reflections, $\quad p=$ parameters used.
$220 \mathrm{mg}$ (0.7 mmol) 1, $100 \mathrm{ml} \mathrm{Et}{ }_{2} \mathrm{O}$. Yield: $310 \mathrm{mg}, 50 \%$ based on 1 .

M.p.: $\left[{ }^{\circ} \mathrm{C}\right]$ dec. IR $(\mathrm{NaCl}):\left[\mathrm{cm}^{-1}\right] 2069$ (s) [ $\left.v_{\mathrm{C} \equiv \mathrm{C}}\right]$. ${ }^{1} \mathrm{H}-\mathrm{NMR}\left(\mathrm{CDCl}_{3}\right):[\delta]-0.03\left(\mathrm{~s}, 9 \mathrm{H}, \mathrm{Si} M e_{3}\right), 1.64(\mathrm{~s}$, $\left.2 \mathrm{H}, \mathrm{TiCH}_{2}\right), 2.22$ (s, $12 \mathrm{H}, \mathrm{NMe}$ ), 7.10 (s, $2 \mathrm{H}, \mathrm{C}_{6} \mathrm{H}_{2}$ ). ${ }^{13} \mathrm{C}\left\{{ }^{1} \mathrm{H}\right\}$-NMR $\left(\mathrm{CDCl}_{3}\right)$ : [ $\left.\delta\right] 3.0\left(\mathrm{Si}_{\mathrm{Me}}\right), 45.4(\mathrm{NMe})$, $63.9\left(\mathrm{CH}_{2}\right), 81.0\left(\mathrm{TiCH}_{2}\right), 112.9\left(C_{5} \mathrm{H}_{5}\right), 123.8(\mathrm{TiC} \equiv C)$, $125.4\left({ }^{i} \mathrm{C} / \mathrm{C}_{6} \mathrm{H}_{2}\right), 130.2\left(\mathrm{CH} / \mathrm{C}_{6} \mathrm{H}_{2}\right), 131.0\left({ }^{i} \mathrm{C} / \mathrm{C}_{6} \mathrm{H}_{2}\right)$, $138.6 \quad\left({ }^{i} \mathrm{C} / \mathrm{C}_{6} \mathrm{H}_{2}\right), \quad 143.7 \quad(\mathrm{TiC} \equiv \mathrm{C})$. Anal. Calc. for $\mathrm{C}_{28} \mathrm{H}_{39} \mathrm{IN}_{2} \mathrm{SiTi}$ (606.52): C, 55.45; H, 6.48; N, 4.62; $\mathrm{Si}$, 4.63. A satisfying elemental analysis could not be obtained.

\subsection{Synthesis of $\{\mathrm{Ti}\} \mathrm{C} \equiv \mathrm{C} \mathrm{C}_{6} \mathrm{H}_{4} \mathrm{CN}-4$ (5)}

To a stirring $\mathrm{Et}_{2} \mathrm{O}$ solution $\left(\begin{array}{lll}150 & \mathrm{ml}\end{array}\right)$ of $\mathrm{LiC} \equiv \mathrm{CC}_{6} \mathrm{H}_{4} \mathrm{CN}-4(150 \mathrm{mg}, 1.1 \mathrm{mmol})$ was added $\mathbf{1}$ (340 $\mathrm{mg}, 1.1 \mathrm{mmol})$ at $-78^{\circ} \mathrm{C}$. After stirring for $12 \mathrm{~h}$ $\left(25^{\circ} \mathrm{C}\right)$, the reaction mixture was evaporated. The resulting residue was extracted with pentane $(3 \times 10 \mathrm{ml})$ and $\mathrm{Et}_{2} \mathrm{O}(4 \times 20 \mathrm{ml})$ and filtered through a pad of Celite. Evaporation of the combined $\mathrm{Et}_{2} \mathrm{O}$ extracts yielded 5 (300 mg, 70\% yield based on 1) as a dark orange solid.

M.p.: $\left[{ }^{\circ} \mathrm{C}\right] 153$ (dec). IR (KBr): [cm $\left.{ }^{-1}\right] 2224$ (s) [ $\left.v_{\mathrm{CN}}\right]$, $2078(\mathrm{~s})\left[v_{\mathrm{C}=\mathrm{C}}\right] .{ }^{1} \mathrm{H}-\mathrm{NMR}\left(\mathrm{CDCl}_{3}\right):[\delta]-0.02(\mathrm{~s}, 9 \mathrm{H}$, $\left.\mathrm{Si} M e_{3}\right), 1.75\left(\mathrm{~s}, 2 \mathrm{H}, \mathrm{CH}_{2}\right), 6.29\left(\mathrm{~s}, 10 \mathrm{H}, \mathrm{C}_{5} H_{5}\right)$, 7.2-7.6 (m, $\left.4 \mathrm{H}, \mathrm{C}_{6} H_{4}\right) \cdot{ }^{13} \mathrm{C}\left\{{ }^{1} \mathrm{H}\right\}-\mathrm{NMR}\left(\mathrm{CDCl}_{3}\right):[\delta]$ $3.0(\mathrm{SiMe}), 83.8\left(\mathrm{CH}_{2}\right), 109.1(\mathrm{CN}), 113.1\left(C_{5} \mathrm{H}_{5}\right)$, $122.2(\mathrm{TiC} \equiv C), 130.4\left({ }^{i} C / \mathrm{C}_{6} \mathrm{H}_{4}\right), 130.7\left({ }^{i} C / \mathrm{C}_{6} \mathrm{H}_{4}\right), 130.8$ $\left(\mathrm{CH} / \mathrm{C}_{6} \mathrm{H}_{4}\right), 131.8\left(\mathrm{CH} / \mathrm{C}_{6} \mathrm{H}_{4}\right), 148.8(\mathrm{TiC} \equiv \mathrm{C}) . \mathrm{FAB}-$ MS $\left[m / z\right.$ (rel. int.)]: $304(60)\left[\mathrm{M}-\mathrm{C}_{4} \mathrm{H}_{11} \mathrm{Si}\right]^{+}, 265$ (70)

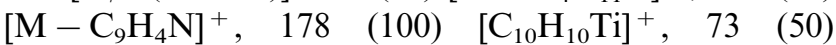
$\left[\mathrm{C}_{3} \mathrm{H}_{9} \mathrm{Si}\right]^{+}$. Anal. Calc. for $\mathrm{C}_{23} \mathrm{H}_{25} \mathrm{NSiTi}$ (391.45): C, 70.57 ; H, 6.44; N, 3.58. Found: C, 70.39; H, 6.36; N, 3.52 .

\subsection{Synthesis of $\{\mathrm{Ti}\} \mathrm{C} \equiv \mathrm{CC}_{5} \mathrm{H}_{4} \mathrm{~N}-4$ (6)}

Experimental procedures and work-up are the same as described for the synthesis of 5. Experimental details: $\mathrm{LiC} \equiv \mathrm{CC}_{5} \mathrm{H}_{4} \mathrm{~N}-4(100 \mathrm{mg}, 0.9 \mathrm{mmol}), \mathbf{1}(270 \mathrm{mg}, 0.9$ $\mathrm{mmol}$ ), $150 \mathrm{ml} \mathrm{Et}{ }_{2} \mathrm{O}$. Yield: $240 \mathrm{mg}, 75 \%$ based on $\mathbf{1}$.

M.p.: [ $\left.{ }^{\circ} \mathrm{C}\right]$ 128. IR (KBr): [cm $\left.{ }^{-1}\right] 2079$ (s) [ $\left.v_{\mathrm{C}=\mathrm{C}}\right]$. ${ }^{1} \mathrm{H}-\mathrm{NMR}\left(\mathrm{CDCl}_{3}\right):[\delta]-0.01$ (s, $\left.9 \mathrm{H}, \mathrm{Si} \mathrm{Me}_{3}\right), 1.72(\mathrm{~s}$, $\left.2 \mathrm{H}, \mathrm{CH}_{2}\right), 6.25\left(\mathrm{~s}, 10 \mathrm{H}, \mathrm{C}_{5} H_{5}\right), 7.0-7.1(\mathrm{~m}, 2 \mathrm{H}$, $\left.\mathrm{C}_{5} H_{4} \mathrm{~N}\right), 8.3-8.5\left(\mathrm{~m}, 2 \mathrm{H}, \mathrm{C}_{5} H_{4} \mathrm{~N}\right) .{ }^{13} \mathrm{C}\left\{{ }^{1} \mathrm{H}\right\}-\mathrm{NMR}$ $\left(\mathrm{CDCl}_{3}\right):[\delta] 3.0(\mathrm{SiMe}), 87.2\left(\mathrm{CH}_{2}\right), 113.2\left(C_{5} \mathrm{H}_{5}\right)$, $121.0(\mathrm{TiC} \equiv C), 124.5\left(C H / \mathrm{C}_{5} \mathrm{H}_{4} \mathrm{~N}\right), 133.4\left({ }^{i} \mathrm{C} / \mathrm{C}_{5} \mathrm{H}_{4} \mathrm{~N}\right)$, $148.9(\mathrm{TiC} \equiv \mathrm{C}), 149.4\left(\mathrm{CH} / \mathrm{C}_{5} \mathrm{H}_{4} \mathrm{~N}\right)$. FAB-MS $[\mathrm{m} / z$ (rel. int.)]: 368 (20) $[\mathrm{M}+\mathrm{H}]^{+}, 280 \quad$ (40) $[\mathrm{M}+\mathrm{H}-$ $\left.\mathrm{C}_{4} \mathrm{H}_{12} \mathrm{Si}\right]^{+}, 178(30)\left[\mathrm{C}_{10} \mathrm{H}_{10} \mathrm{Ti}\right]^{+}, 73(80)\left[\mathrm{C}_{3} \mathrm{H}_{9} \mathrm{Si}\right]^{+}$. Anal. Calc. for $\mathrm{C}_{21} \mathrm{H}_{25} \mathrm{NSiTi}$ (369.43): C, 68.65; H, 6.86; N, 3.68; Si, 7.65. Found: C, 68.53; H, 6.44; N, 3.81; Si, 7.22 . 


\subsection{Synthesis of $\{T i\} C \equiv C F c$ (7)}

Experimental procedures and work-up are the same as described for the synthesis of 5. Experimental details: $200 \mathrm{mg}$ (0.9 mmol) LiC $\equiv \mathrm{CFc}, 270 \mathrm{mg}(0.9 \mathrm{mmol}) \mathbf{1}, 150$ $\mathrm{ml} \mathrm{Et}{ }_{2} \mathrm{O}$. Yield: $260 \mathrm{mg}, 60 \%$ based on $\mathbf{1}$.

M.p.: [ $\left.{ }^{\circ} \mathrm{C}\right]$ 139. IR (KBr): $\left[\mathrm{cm}^{-1}\right] 2052$ (s) [ $\left.v_{\mathrm{C}=\mathrm{C}}\right]$. ${ }^{1} \mathrm{H}-\mathrm{NMR}\left(\mathrm{CDCl}_{3}\right):[\delta]-0.2\left(\mathrm{~s}, 9 \mathrm{H}, \mathrm{Si} M e_{3}\right), 1.57(\mathrm{~s}, 2$ $\left.\mathrm{H}, \mathrm{CH}_{2}\right), 4.12\left(\mathrm{t},{ }^{3} J_{\mathrm{HH}}=1.8 \mathrm{~Hz}, 2 \mathrm{H}, \mathrm{C}_{5} H_{4}\right), 4.16(\mathrm{~s}, 5$ $\left.\mathrm{H}, \mathrm{C}_{5} H_{5}\right), 4.24\left(\mathrm{t},{ }^{3} J_{\mathrm{HH}}=1.8 \mathrm{~Hz}, 2 \mathrm{H}, \mathrm{C}_{5} H_{4}\right), 6.25(\mathrm{~s}, 10$ $\left.\mathrm{H}, \mathrm{C}_{5} \mathrm{H}_{5}\right) \cdot{ }^{13} \mathrm{C}\left\{{ }^{1} \mathrm{H}\right\}-\mathrm{NMR}\left(\mathrm{CDCl}_{3}\right):[\delta] 3.0\left(\mathrm{SiM} e_{3}\right), 68.2$ $\left(\mathrm{CH} / \mathrm{C}_{5} \mathrm{H}_{4}\right), 69.6\left(\mathrm{C}_{5} \mathrm{H}_{5}\right), 70.1\left({ }^{i} \mathrm{C} / \mathrm{C}_{5} \mathrm{H}_{4}\right), 70.8(\mathrm{CH} /$ $\left.\mathrm{C}_{5} \mathrm{H}_{4}\right), 77.7\left(\mathrm{TiCH}_{2}\right), 112.7 \quad\left(C_{5} \mathrm{H}_{5}\right), 122.8 \quad(\mathrm{TiC} \equiv C)$, $144.1 \quad(\mathrm{Ti} C \equiv \mathrm{C})$. FAB-MS $[\mathrm{m} / \mathrm{z}$ (rel. int.)]: 476 (10) $[\mathrm{M}]^{+}, 460$ (10) $[\mathrm{M}-\mathrm{Me}]^{+}, 418$ (90) $\left[\mathrm{M}-\mathrm{SiMe}_{2}\right]^{+}$, 296 (100) $\left[\mathrm{M}-\mathrm{SiMe}_{2}-\mathrm{C}_{5} \mathrm{H}_{5} \mathrm{Fe}\right]^{+}, 266$ (100) $[\mathrm{M}-$ $\left.\mathrm{C}_{12} \mathrm{H}_{9} \mathrm{Fe}\right]^{+}, 210\left[\mathrm{C}_{12} \mathrm{H}_{9} \mathrm{Fe}\right]^{+}, 178$ (60) $\left[\mathrm{C}_{10} \mathrm{H}_{10} \mathrm{Ti}\right]^{+}$. Anal. Calc. for $\mathrm{C}_{26} \mathrm{H}_{30} \mathrm{FeSiTi}$ (474.37): C, 65.83; H, 6.37. Found: $\mathrm{C}, 65.72 ; \mathrm{H}, 6.34$.

\subsection{Synthesis of $\{T i\} C \equiv C C_{6} H_{4} C \equiv C\{T i\}-4(\boldsymbol{8})$}

To a $\mathrm{Et}_{2} \mathrm{O}$ solution $(150 \mathrm{ml})$ of $1,4-(\mathrm{LiC} \equiv \mathrm{C})_{2} \mathrm{C}_{6} \mathrm{H}_{4}$ $(130 \mathrm{mg}, 0.9 \mathrm{mmol})$ was added $1(540 \mathrm{mg}, 1.8 \mathrm{mmol})$ at $-78^{\circ} \mathrm{C}$. After stirring for $12 \mathrm{~h}\left(25^{\circ} \mathrm{C}\right)$, the solvent was removed in vacuo. The resulting residue was then extracted with pentane $(3 \times 10 \mathrm{ml}), \mathrm{Et}_{2} \mathrm{O}(3 \times 10 \mathrm{ml})$ and then with $\mathrm{CH}_{2} \mathrm{Cl}_{2}(3 \times 20 \mathrm{ml})$ and filtered through a pad of Celite. The combined $\mathrm{CH}_{2} \mathrm{Cl}_{2}$ extracts were evaporated to dryness to yield $8(310 \mathrm{mg}, 50 \%$ yield based on 1) as yellow solid.

M.p.: $\left[{ }^{\circ} \mathrm{C}\right]>200$. IR (KBr): [ $\left.\mathrm{cm}^{-1}\right] 2076$ (s) [ $\left.v_{\mathrm{C}=\mathrm{C}}\right]$. ${ }^{1} \mathrm{H}-\mathrm{NMR}\left(\mathrm{CDCl}_{3}\right)$ : $\left.[\delta]-0.04(\mathrm{~s}, 18 \mathrm{H}, \mathrm{SiMe})_{3}\right), 1.65$ (s, $\left.4 \mathrm{H}, \mathrm{CH}_{2}\right), 6.27\left(\mathrm{~s}, 20 \mathrm{H}, \mathrm{C}_{5} H_{5}\right), 7.10\left(\mathrm{~s}, 4 \mathrm{H}, \mathrm{C}_{6} H_{4}\right)$. ${ }^{13} \mathrm{C}\left\{{ }^{1} \mathrm{H}\right\}$-NMR $\left.\left(\mathrm{CDCl}_{3}\right):[\delta] 3.0(\mathrm{SiMe})_{3}\right), 81.5\left(\mathrm{CH}_{2}\right)$, $112.9\left(C_{5} \mathrm{H}_{5}\right), 124.3(\mathrm{TiC} \equiv C), 130.5\left(\mathrm{CH} / \mathrm{C}_{6} \mathrm{H}_{4}\right), 140.1$ $(\mathrm{TiC} \equiv \mathrm{C}) . \quad$ FAB-MS $[\mathrm{m} / \mathrm{z}$ (rel. int.)]: $265 \quad$ (80) $\left[\mathrm{C}_{14} \mathrm{H}_{21} \mathrm{SiTi}\right]^{+}, 178(100)\left[\mathrm{C}_{10} \mathrm{H}_{10} \mathrm{Ti}\right]^{+}$. Anal. Calc. for $\mathrm{C}_{38} \mathrm{H}_{46} \mathrm{Si}_{2} \mathrm{Ti}_{2}$ (654.77): C, 69.71; H, 6.81; Si, 8.58. Found: C, 69.56; H, 6.81; Si, 8.36.

\subsection{Reaction of $\{\mathrm{Ti}\} \mathrm{C} \equiv \mathrm{CSiMe}_{3}$ (2) with $[\mathrm{CuCl}]_{n}$}

$[\mathrm{CuCl}]_{n}(15 \mathrm{mg}, 0.15 \mathrm{mmol})$ and $2(60 \mathrm{mg}, 0.15$ mmol) were mixed and cooled to $-78^{\circ} \mathrm{C}$. Cooled THF $\left(-78^{\circ} \mathrm{C}, 10 \mathrm{ml}\right)$ was then added via a syringe. While the reaction mixture was stirred $\left(-78^{\circ} \mathrm{C}, 2 \mathrm{~h}\right)$ it changed colour from orange to red and became clear.

\subsubsection{Method $A$}

Then, the reaction mixture was allowed to warm to $25^{\circ} \mathrm{C}$. Monitoring the reaction mixture (IR), the development of an absorption band assigned to $\left[\mathrm{CuC} \equiv \mathrm{CSiMe}_{3}\right]_{n}$ was observed and the band at 1920 $\mathrm{cm}^{-1}$ (9) disappeared. After extraction of the resulting solid with pentane $(3 \times 10 \mathrm{ml})$, the ${ }^{1} \mathrm{H}-\mathrm{NMR}$ spectrum of the evaporated (in vacuo) residue revealed the presence of $\mathbf{1}$.

\subsubsection{Method B}

Then, the THF was removed (in vacuo, $-78^{\circ} \mathrm{C}$ ) and the orange residue was extracted with pentane $\left(-78^{\circ} \mathrm{C}\right.$, $3 \times 10 \mathrm{ml}), \mathrm{Et}_{2} \mathrm{O}\left(-78^{\circ} \mathrm{C}, 3 \times 10 \mathrm{ml}\right)$ and $\mathrm{THF}(-$ $78^{\circ} \mathrm{C}, 3 \times 10 \mathrm{ml}$ ) and filtered through a pad of Celite. The combined THF extracts were evaporated (in vacuo, $-78^{\circ} \mathrm{C}$ ) to yield an orange residue $(30 \mathrm{mg})$.

M.p.: $\left[{ }^{\circ} \mathrm{C}\right]$ dec. IR (KBr): [cm $\left.{ }^{-1}\right] 1920$ (s) [ $\left.v_{\mathrm{C}=\mathrm{C}}\right], 1894$ (s) $\left[v_{\mathrm{C}=\mathrm{C}}\right] \cdot{ }^{1} \mathrm{H}-\mathrm{NMR}\left(\mathrm{d}_{8}-\mathrm{THF}\right):[\delta] 0.11\left(\mathrm{Si} M e_{3}\right), 0.22$ $\left(\mathrm{Si} M e_{3}\right), 1.55\left(\mathrm{CH}_{2}\right), 6.17\left(\mathrm{C}_{5} H_{5}\right)$. FAB-MS $[\mathrm{m} / z$ (rel. int.)]: $922(5)\left[\mathrm{M}^{+}\right], 425(15)\left[\mathrm{C}_{19} \mathrm{H}_{30} \mathrm{CuSi}_{2} \mathrm{Ti}\right]^{+}, 178$ (100) $\left[\mathrm{C}_{10} \mathrm{H}_{10} \mathrm{Ti}\right]^{+}$.

\subsection{Reaction of $\{\mathrm{Ti}\} \mathrm{C} \equiv \mathrm{CSiMe}_{3}$ (2) with $\left[\mathrm{Cu}(\mathrm{NCMe})_{4}\right]\left[\mathrm{BF}_{4}\right]$}

Experimental conditions were the same as for the reaction of $\mathbf{2}$ with $\mathbf{9}$ - see Method B above. Experimental details: 10 (30 mg, $0.1 \mathrm{mmol}), 2$ (70 $\mathrm{mg}, 0.2 \mathrm{mmol}$ ), THF (10 ml).

After stirring ( $2 \mathrm{~h})$, the suspension was evaporated in vacuo. The yellow residue was extracted $\left(-78^{\circ} \mathrm{C}\right)$ with pentane $(3 \times 10 \mathrm{ml}), \mathrm{Et}_{2} \mathrm{O}(3 \times 10 \mathrm{ml})$, THF $(3 \times 10 \mathrm{ml})$ and $\mathrm{CH}_{2} \mathrm{Cl}_{2}(3 \times 10 \mathrm{ml})$. After filtration through pad of Celite and evaporation $\left(-78^{\circ} \mathrm{C}\right)$ of the combined $\mathrm{CH}_{2} \mathrm{Cl}_{2}$ extracts, a yellow solid (10 mg) was obtained.

IR spectroscopy carried out on the yellow residue revealed no characteristic bands in the region typical for $v_{\mathrm{C} \equiv \mathrm{C}}$ and the ${ }^{1} \mathrm{H}-\mathrm{NMR}$ spectrum exhibited a number of uncharacteristic signals.

\subsection{Reaction of $\{\mathrm{Ti}\} \mathrm{C} \equiv \mathrm{CFC}$ (7) with $\mathrm{Mg}$}

Activated $\mathrm{Mg}(30 \mathrm{mg}, 1.3 \mathrm{mmol})$ and $7(50 \mathrm{mg}, 0.1$ $\mathrm{mmol})$ were mixed. Then, THF $(20 \mathrm{ml})$ was added and the solution stirred $\left(10 \mathrm{~h}, 25^{\circ} \mathrm{C}\right)$. No colour change was observed. After filtration of the reaction mixture through a pad of Celite, the red solution was evaporated to dryness (in vacuo) to yield a red brown solid (45 mg). IR and ${ }^{1} \mathrm{H}-\mathrm{NMR}$ revealed the presence of 7 solely.

\subsection{Reaction of $\{\mathrm{Ti}\} \mathrm{C} \equiv \mathrm{CFc}$ (7) with $\mathrm{Na}$}

To Na metal (10 mg, $0.4 \mathrm{mmol})$ was added a solution of $7(150 \mathrm{mg}, 0.3 \mathrm{mmol})$ in THF $\left(20 \mathrm{ml}, 0^{\circ} \mathrm{C}\right)$. During the course of the reaction a precipitate formed. After stirring $\left(0^{\circ} \mathrm{C}, 6 \mathrm{~h}\right)$ the mixture was evaporated (in vacuo). The residue was then extracted with pentane $(3 \times 10 \mathrm{ml}), \mathrm{Et}_{2} \mathrm{O}(3 \times 20 \mathrm{ml})$ and $\mathrm{THF}(3 \times 10 \mathrm{ml})$ and filtered through a pad of Celite. The $\mathrm{Et}_{2} \mathrm{O}$ and THF extracts were removed in vacuo to yield a brown solid. ${ }^{1} \mathrm{H}-\mathrm{NMR}$ investigation of the $\mathrm{Et}_{2} \mathrm{O}$ and THF residues revealed a signal pattern which could not be assigned 
unambiguously. Also, the IR spectra revealed non-diagnostic absorption bands.

\subsection{Reaction of $\{\mathrm{Ti}\} \mathrm{C} \equiv \mathrm{CFc}$ (7) with $\mathrm{Ag}\left[\mathrm{BF}_{4}\right]$}

To a light protected Schlenk flask containing $\mathrm{Ag}\left[\mathrm{BF}_{4}\right]$ $(40 \mathrm{mg}, 0.2 \mathrm{mmol})$ was added a THF solution $(30 \mathrm{ml}$, $\left.0^{\circ} \mathrm{C}\right)$ of $7(97 \mathrm{mg}, 0.2 \mathrm{mmol})$. The reaction mixture was stirred $\left(5 \mathrm{~h}, 0^{\circ} \mathrm{C}\right)$ and then the solvent is removed (in vacuo). The green residue was extracted with pentane $(3 \times 10 \mathrm{ml}), \mathrm{Et}_{2} \mathrm{O}(3 \times 10 \mathrm{ml})$ and THF $(3 \times 20 \mathrm{ml})$ and then filtered through a pad of Celite. Then, the extracts were evaporated to dryness (in vacuo). The residue of the pentane extracts contained $\mathrm{HC} \equiv \mathrm{Fc}$, identified by its IR and ${ }^{1} \mathrm{H}-\mathrm{NMR}$ spectra. After evaporation of the THF extracts, a green solid was obtained. ${ }^{1} \mathrm{H}-\mathrm{NMR}$ spectroscopic investigation showed paramagnetism and the IR spectrum exhibited uncharacteristic absorption bands.

\subsection{Reaction of $\{\mathrm{Ti}\} \mathrm{C} \equiv \mathrm{CC}_{6} \mathrm{H}_{4} \mathrm{CN}-4$ (5) with $\left[\{\mathrm{Pt}\} \cdot \mathrm{H}_{2} \mathrm{O}\right]\left[\mathrm{BF}_{4}\right](\mathbf{1 2})$}

Compound 5 (50 mg, $0.13 \mathrm{mmol}$ ) was mixed with $\mathbf{1 2}$ $(63 \mathrm{mg}, 0.13 \mathrm{mmol})$ and dissolved in THF $\left(-40^{\circ} \mathrm{C}, 20\right.$ $\mathrm{ml})$. In the course of the reaction, a yellow precipitate formed. After stirring $\left(-40^{\circ} \mathrm{C}, 3 \mathrm{~h}\right)$ the solution was allowed to warm up $\left(25^{\circ} \mathrm{C}\right)$ and evaporated. The residue was then extracted with $\mathrm{Et}_{2} \mathrm{O}(2 \times 20 \mathrm{ml})$, THF $(3 \times 10 \mathrm{ml})$ and $\mathrm{CH}_{2} \mathrm{Cl}_{2}(2 \times 10 \mathrm{ml})$ and filtered through a pad of Celite. The combined $\mathrm{CH}_{2} \mathrm{Cl}_{2}$ extracts were then concentrated to ca. $5 \mathrm{ml}$ and $15 \mathrm{ml}$ pentane was added. The supernatant solution was removed and the yellow residue dried in vacuo.

\subsection{Reaction of $\{\mathrm{Ti}\} \mathrm{C} \equiv \mathrm{CC}_{6} \mathrm{H}_{4} \mathrm{CN}-4$ (5) with $[\{P t\} \cdot N C M e][O T f](\mathbf{1 3})$}

Experimental conditions and work-up were the same as described for the reaction of 5 with 13. Experimental details: 5 (150 mg, $0.4 \mathrm{mmol}), \mathbf{1 3}(150 \mathrm{mg}, 0.3 \mathrm{mmol})$, THF (40 ml).

\subsection{Reaction of $\{\mathrm{Ti}\} \mathrm{C} \equiv \mathrm{CC}_{5} \mathrm{H}_{4} \mathrm{~N}-4$ (6) with $\left[\{\mathrm{Pt}\} \cdot \mathrm{H}_{2} \mathrm{O}\right]\left[\mathrm{BF}_{4}\right](\mathbf{1 2})$}

Experimental conditions and work-up were the same as described for the reaction of $\mathbf{5}$ with 12. Experimental details: 6 (100 mg, $0.3 \mathrm{mmol}), \mathbf{1 2}(120 \mathrm{mg}, 0.3 \mathrm{mmol})$, THF $(50 \mathrm{ml})$.

\subsection{Reaction of $\{\mathrm{Ti}\} \mathrm{C} \equiv \mathrm{CC}_{5} \mathrm{H}_{4} \mathrm{~N}-4$ (6) with $[\{P t\} \cdot N C M e][O T f](\mathbf{1 3})$}

Experimental conditions and work-up were the same as described for the reaction of 6 with 13. Experimental details: 6 (50 mg, $0.14 \mathrm{mmol}), 13$ (75 mg, $0.13 \mathrm{mmol})$, THF (20 ml).

In each experiment, the IR and ${ }^{1} \mathrm{H}-\mathrm{NMR}$ spectroscopy revealed an uncharacteristic signal pattern of the yellow residue obtained which could not be assigned unequivocally.

\subsection{Synthesis of $\left[\{T i\} C \equiv C C_{6} H_{4} C N-4\right]\{R u\}$}

Compound $5 \quad(105 \quad \mathrm{mg}, \quad 0.3 \quad \mathrm{mmol})$ and $\{\mathrm{Ru}\} \mathrm{N} \equiv \mathrm{N}\{\mathrm{Ru}\}$ (14) (106 mg, $0.15 \mathrm{mmol})$ were mixed. Addition of THF $\left(50 \mathrm{ml}, 0^{\circ} \mathrm{C}\right)$ resulted in a brown solution which turned intensively red after ca. $15 \mathrm{~min}$. The mixture was stirred at $0^{\circ} \mathrm{C}(3 \mathrm{~h})$ and then concentrated to ca. $5 \mathrm{ml}$. Then $20 \mathrm{ml}$ of pentane were added, the precipitate washed twice with pentane and then dried in vacuo. Product 15 (100 mg, 90\% yield based on 5) was thus obtained as dark red solid.

M.p.: $\left[{ }^{\circ} \mathrm{C}\right] 123(\mathrm{dec}) . \mathrm{IR}(\mathrm{KBr}):\left[\mathrm{cm}^{-1}\right] 2197$ (s) [ $\left.v_{\mathrm{CN}}\right]$, 2077 (s) $\left[v_{\mathrm{C}=\mathrm{C}}\right] .{ }^{1} \mathrm{H}-\mathrm{NMR}\left(\mathrm{CDCl}_{3}\right):[\delta]-0.3(\mathrm{~s}, 9 \mathrm{H}$, $\mathrm{Si} \mathrm{Me}_{3}$ ), 1.73 (s, $\left.2 \mathrm{H}, \mathrm{CH}_{2}\right), 2.63$ (s, $\left.12 \mathrm{H}, \mathrm{N} M e_{2}\right), 4.09$ (s, $\left.4 \mathrm{H}, \mathrm{CH}_{2}\right), 6.29\left(\mathrm{~s}, 10 \mathrm{H}, \mathrm{C}_{5} H_{5}\right), 7.1-7.7(\mathrm{~m}, 3 \mathrm{H}$, $\left.\mathrm{C}_{6} \mathrm{H}_{3}\right), \quad 7.2-7.5 \quad\left(\mathrm{~m}, \quad 4 \quad \mathrm{H}, \quad \mathrm{C}_{6} \mathrm{H}_{4}\right) .{ }^{13} \mathrm{C}\left\{{ }^{1} \mathrm{H}\right\}-\mathrm{NMR}$ $\left.\left(\mathrm{CDCl}_{3}\right):[\delta] 3.0(\mathrm{SiMe})_{3}\right), 54.5\left(\mathrm{NMe}_{2}\right), 71.2\left(\mathrm{CH}_{2}\right), 83.3$ $\left(\mathrm{TiCH}_{2}\right), \quad 110.8(\mathrm{CN}), \quad 113.1 \quad\left(\mathrm{C}_{5} \mathrm{H}_{5}\right), \quad 118.9(\mathrm{CH} /$ $\left.\mathrm{C}_{5} \mathrm{H}_{3} \mathrm{~N}\right), 122.7 \quad\left({ }^{i} \mathrm{C} / \mathrm{C}_{6} \mathrm{H}_{4}\right), 125.3(\mathrm{TiC} \equiv \mathrm{C}), 129.2\left({ }^{i} \mathrm{C} /\right.$ $\left.\mathrm{C}_{6} \mathrm{H}_{4}\right), 130.8\left(\mathrm{CH} / \mathrm{C}_{6} \mathrm{H}_{4}\right), 132.0 \quad\left({ }^{i} \mathrm{C} / \mathrm{C}_{5} \mathrm{H}_{3} \mathrm{~N}\right), 132.4$ $\left(\mathrm{CH} / \mathrm{C}_{6} \mathrm{H}_{4}\right), 149.0(\mathrm{TiC} \equiv \mathrm{C}), 163.2\left(\mathrm{CH} / \mathrm{C}_{5} \mathrm{H}_{3} \mathrm{~N}\right)$. FABMS $\left[m / z\right.$ (rel. int.)]: $756(5)[\mathrm{M}]^{+}, 721(5)[\mathrm{M}-\mathrm{Cl}]^{+}$, $365 \quad$ (60) $\quad\left[\mathrm{C}_{11} \mathrm{H}_{19} \mathrm{Cl}_{2} \mathrm{~N}_{3} \mathrm{Ru}\right]^{+}, \quad 329 \quad$ (100) $\left[\mathrm{C}_{11} \mathrm{H}_{19} \mathrm{ClN}_{3} \mathrm{Ru}\right]^{+}$. Anal. Calc. for $\mathrm{C}_{34} \mathrm{H}_{44} \mathrm{Cl}_{2} \mathrm{~N}_{4} \mathrm{RuSiTi}$ (756.75): C, 53.96; H, 5.86; N, 7.40; Si, 3.71. Found: C, 54.15; H, 5.76; N, 7.26; Si, 3.84.

\subsection{Synthesis of $\left[\{T i\} C \equiv C C_{5} H_{4} N-4\right]\{R u\}$ (16)}

Experimental procedures and work-up are the same as described for the synthesis of 5. Experimental details: 6 (45 mg, $0.12 \mathrm{mmol}),\{\mathrm{Ru}\} \mathrm{N} \equiv \mathrm{N}\{\mathrm{Ru}\}$ (14) (45 mg, 0.06 mmol), $20 \mathrm{ml}$ THF. Yield: $80 \mathrm{mg}, 90 \%$ based on 6 .

M.p.: [ $\left.{ }^{\circ} \mathrm{C}\right] 125$ (dec). IR (KBr): $\left[\mathrm{cm}^{-1}\right] 2083$ (s) $\left.\left[v_{\mathrm{C}=\mathrm{C}}\right] .{ }^{1} \mathrm{H}-\mathrm{NMR}\left(\mathrm{CDCl}_{3}\right):[\delta]-0.3(\mathrm{~s}, 9 \mathrm{H}, \mathrm{SiMe})_{3}\right)$, 1.79 (s, $\left.2 \mathrm{H}, \mathrm{CH}_{2}\right), 2.39$ (s, $12 \mathrm{H}, \mathrm{NMe}$ ), $4.04(\mathrm{~s}, 4 \mathrm{H}$, $\left.\mathrm{CH}_{2}\right), 6.31\left(\mathrm{~s}, 10 \mathrm{H}, \mathrm{C}_{5} \mathrm{H}_{5}\right), 7.0-7.1\left(\mathrm{~m}, 2 \mathrm{H}, \mathrm{C}_{5} \mathrm{H}_{4} \mathrm{~N}\right)$, 7.1-7.3 (m, $\left.3 \mathrm{H}, \mathrm{C}_{5} \mathrm{H}_{3} \mathrm{~N}\right)$, 9.5-9.6 (m, $\left.2 \mathrm{H}, \mathrm{C}_{5} \mathrm{H}_{4} \mathrm{~N}\right)$.

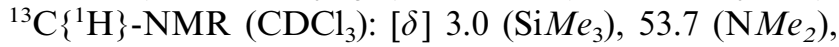
$72.3\left(\mathrm{CH}_{2}\right), 83.8\left(\mathrm{TiCH}_{2}\right), 113.2\left(\mathrm{C}_{5} \mathrm{H}_{5}\right), 118.4(\mathrm{CH} /$ $\left.\mathrm{C}_{5} \mathrm{H}_{3} \mathrm{~N}\right), 123.5(\mathrm{TiC} \equiv C), 124.5\left(\mathrm{CH} / \mathrm{C}_{5} \mathrm{H}_{4} \mathrm{~N}\right), 130.5\left({ }^{i} \mathrm{C} /\right.$ $\left.\mathrm{C}_{5} \mathrm{H}_{3} \mathrm{~N}\right), \quad 134.1 \quad\left({ }^{i} \mathrm{C} / \mathrm{C}_{5} \mathrm{H}_{4} \mathrm{~N}\right), \quad 151.1 \quad(\mathrm{TiC} \equiv \mathrm{C}), \quad 156.0$ $\left(\mathrm{CH} / \mathrm{C}_{5} \mathrm{H}_{4} \mathrm{~N}\right), 163.6\left(\mathrm{CH} / \mathrm{C}_{5} \mathrm{H}_{3} \mathrm{~N}\right)$. FAB-MS $[m / z$ (rel. int.)]: $734(10)[\mathrm{M}+\mathrm{H}]^{+}, 697(10)[\mathrm{M}-\mathrm{Cl}]^{+}, 365$ (5) $\left[\mathrm{C}_{11} \mathrm{H}_{19} \mathrm{Cl}_{2} \mathrm{~N}_{3} \mathrm{Ru}\right]^{+}, 329(100)\left[\mathrm{C}_{11} \mathrm{H}_{19} \mathrm{ClN}_{3} \mathrm{Ru}\right]^{+}$. Anal. Calc. for $\mathrm{C}_{32} \mathrm{H}_{44} \mathrm{Cl}_{2} \mathrm{~N}_{4} \mathrm{RuSiTi}$ (732.73): C, 52.45; H, $6.05 ; \mathrm{N}, 7.65 ; \mathrm{Si}, 3.83$. A satisfying elemental analysis could not be obtained. 


\subsection{Synthesis of $\{R u\} N C P h(17)$}

A solution of $\{\mathrm{Ru}\} \mathrm{N} \equiv \mathrm{N}\{\mathrm{Ru}\} \quad$ (14) $\quad(128 \mathrm{mg}, \quad 0.2$ $\mathrm{mmol})$ and PhCN (40 mg, $0.4 \mathrm{mmol})$ in THF (30 ml) was stirred for $1 \mathrm{~h}$. During the course of the reaction the colour of the solution turned from brown to red and the turbidity disappeared. The reaction mixture was then concentrated to ca. $5 \mathrm{ml}$ and pentane $(50 \mathrm{ml})$ added. The supernatant liquid was carefully decanted and the residue dried in vacuo to yield 17 (150 mg, 95\% yield based on 14) as brown solid.

M.p.: [ $\left.{ }^{\circ} \mathrm{C}\right]$ 148. IR (KBr): [cm $\left.{ }^{-1}\right] 2214$ (s) [ $\left.v_{\mathrm{CN}}\right]$. ${ }^{1} \mathrm{H}-\mathrm{NMR}\left(\mathrm{CDCl}_{3}\right):[\delta] 2.68$ (s, $\left.12 \mathrm{H}, \mathrm{NMe} 2\right), 4.09$ (s, 4 $\left.\mathrm{H}, \mathrm{CH}_{2}\right), 7.1-7.7\left(\mathrm{~m}, 3 \mathrm{H}, \mathrm{C}_{6} \mathrm{H}_{3}\right) .{ }^{13} \mathrm{C}\left\{{ }^{1} \mathrm{H}\right\}-\mathrm{NMR}$ $\left(\mathrm{CDCl}_{3}\right):[\delta] 54.5\left(\mathrm{NMe} e_{2}\right), 71.2\left(\mathrm{CH}_{2}\right), 110.8(\mathrm{CN})$, $118.9\left(\mathrm{CH} / \mathrm{C}_{5} \mathrm{H}_{3} \mathrm{~N}\right),\left({ }^{i} \mathrm{C} / \mathrm{C}_{6} \mathrm{H}_{4}\right), 130.8\left(\mathrm{CH} / \mathrm{C}_{6} \mathrm{H}_{4}\right), 132.0$ $\left({ }^{i} \mathrm{C} / \mathrm{C}_{5} \mathrm{H}_{3} \mathrm{~N}\right), \quad 132.4\left(\mathrm{CH} / \mathrm{C}_{6} \mathrm{H}_{4}\right), 163.2\left(\mathrm{CH} / \mathrm{C}_{5} \mathrm{H}_{3} \mathrm{~N}\right)$. FAB-MS $\left[m / z\right.$ (rel. int.)]: 467 (15) $[\mathrm{M}]^{+}, 433$ (10) $[\mathrm{M}-\mathrm{Cl}]^{+}, \quad 365 \quad(10) \quad\left[\mathrm{M}-\mathrm{C}_{7} \mathrm{H}_{5} \mathrm{~N}\right]^{+}, \quad 329 \quad$ (20) $\left[\mathrm{C}_{11} \mathrm{H}_{19} \mathrm{ClN}_{3} \mathrm{Ru}\right]^{+}$. Anal. Calc. for $\mathrm{C}_{18} \mathrm{H}_{24} \mathrm{Cl}_{2} \mathrm{~N}_{4} \mathrm{Ru}$ (468.42): C, 46.15; H, 5.16; N, 11.96. A satisfying elemental analysis could not be obtained.

\section{Acknowledgements}

The authors would like to thank the Volkswagenstiftung, the Fonds der Chemischen Industrie and Utrecht University (a 1.5 year stay of S. Back) for financial support. The authors are grateful to the Department of Mass Spectrometry for the recording of the mass spectra. The authors also thank B. Richter for helpful discussions.

\section{References}

[1] (a) S.R. Marder, in: D.W. Bruce, D. O'Hare (Eds.), Inorganic Materials, Wiley, Chichester, 1992. (b) D.R. Kanis, M.A. Ratner, J. Marks, Chem. Rev. 94 (1994) 195. (c) H. Lang, Angew. Chem. 106 (1994) 569; Angew. Chem. Int. Ed. Engl. 33 (1994) 537 and refs. cited therein. (d) U.H.F. Bunz, Angew. Chem. 108 (1996) 1047; Angew. Chem. Int. Ed. Engl. 35 (1996) 968 and refs. cited therein. (e) D. Astruc, Acc. Chem. Res. 30 (1997) 383 and refs. cited therein.

[2] (a) J.D. Williams, Angew. Chem. 96 (1984) 637; Angew. Chem. Int. Ed. Engl. 33 (1994) 690. (b) S.R. Marder, J.W. Perry, Adv. Mater. 5 (1993) 804.

[3] (a) L. Lambert, S. Stadler, G. Bourhill, C. Bräuchle, Angew. Chem. 108 (1996) 710; Angew. Chem. Int. Ed. Engl. 35 (1996) 644. (b) G.U. Bublitz, R. Ortiz, C. Runser, A. Fort, M. Barzonhas, S.R. Marder, S.G. Boxer, J. Am. Chem. Soc. 119 (1997) 2311.

[4] For examples see: (a) Z. Yuen, N.J. Taylor, Y. Sun, T.B. Marder, I.D. Williams, C.T. Cheng, J. Organomet. Chem. 44 (1993) 27. (b) B.J. Joe, C.J. Jones, J.A. McCleverty, D. Boor, G. Cross, J. Organomet. Chem. 464 (1994) 225. (c) A.J. Amoroso, A.M.W. Cargill-Thompson, J.P. Maher, J.A. McCleverty, M.D. Ward, Inorg. Chem. 34 (1995) 4828. (d) V.W.-W. Yam, V.C.-Y.
Lou, K.K. Chang, Organometallics 14 (1995) 2749. (e) A.M. McDonagh, I.R. Whitall, M.G. Humphrey, D.C.R. Hockless, B.W. Skelton, A.H. White, J. Organomet. Chem. 523 (1996) 33. (f) S. Houbrechts, K. Clay, A. Persoons, V. Cardiero, M.P. Gamasa, J. Gimeno, Organometallics 15 (1996) 5266. (g) I.R. Whitall, M.G. Humphrey, M. Samroc, B. Luther-Davies, D.C.R. Hockless, J. Organomet. Chem. 544 (1997) 189. (h) I.R. Whitall, M.G. Humphrey, S. Houbrechts, J. Maes, A. Persoons, S. Schmid, D.C.R. Hockless J. Organomet. Chem. 544 (1997) 277. (i) P. Nguyen, G. Lesley, T.B. Marder, I. Ledaux, J. Zyss, Chem. Mater. 9 (1997) 406. (j) N.D. Jones, M.O. Wolf, D.M. Giaquinta, Organometallics 16 (1997) 1352. k) T. Weyland, C. Lapinte, G. Frapper, M.J. Calhorda, M.F. Halet, L. Toupet, Organometallics 16 (1997) 2024. (k) I.-Y. Wu, J.T. Liu, J. Luo, C.-S. Li, C. Tsai, Y.S. Wen, C.-C. Hsu, F.-F. Yeh, S. Liou, Organometallics 17 (1998) 2188.

[5] For examples see: (a) S.J. Davies, B.F.G. Johnson, J. Lewis, M.S. Khan, J. Organomet. Chem. 401 (1991) C41. (b) M.S. Khan, A.K. Kakkar, S.L. Ingham, P.R. Raithby, J. Lewis, B. Spencer, F. Hittmann, R.H. Friend, J. Organomet. Chem. 472 (1994) 247. (c) M. Brady, W. Weng, Y. Zhou, J.W. Seyler, A.J. Amoroso, A.M. Arif, M. Böhme, G. Frenking, J.A. Gladysz, J. Am. Chem. Soc. 119 (1997) 775. (d) O. Lavastre, J. Plass, P. Bachmann, S. Guesmi, C. Moinet, P.H. Dixneuf, Organometallics 16 (1997) 184. (e) P. Steenwinkel, S.L. James, D.M. Grove, H. Kooijman, A.L. Spek, G. van Koten, Organometallics 16 (1997) 513. (f) M.C. Colbert, J. Lewis, N.J. Long, P.R. Raithby, A.J.P. White, D.J. Williams, J. Chem. Soc. Dalton Trans. (1997) 99. (g) V. Guilleaume, V. Mahies, C. Lapinte, J. Organomet. Chem. 554 (1998) 203. (h) H. Schimanke, R. Gleiter, Organometallics 17 (1998) 275. (i) M.-C. Lagunas, R.A. Gossage, A.L. Spek, G. van Koten, Organometallics 17 (1998) 731. (j) J. Gil-Rubio, M. Laubender, H. Werner, Organometallics 17 (1998) 1202. (k) J. Mata, S. Uriel, E. Peris, R. Llusar, S. Houbrechts, A. Persoons, Organometallics 562 (1998) 197.

[6] For examples see: (a) K. Sonogashira, Y. Fujikura, T. Yatake, N. Toyoshima, S. Takahashi, N. Hagihara, J. Organomet. Chem. 145 (1978) 101. (b) S. Takahashi, Y. Takai, H. Morimoto, K. Sonogashira, J. Chem. Soc. Chem. Commun. (1984) 3. (c) O. Lavastre, M. Even, P.H. Dixneuf, A. Pacreau, J.-V. Vairon, Organometallics 16 (1996) 1530. (d) K. Wärnmark, J.A. Thomas, O. Heyke, J.M. Lehn, Chem. Commun. (1996) 701. (e) P.J. Connors, D. Tsalis, A.L. Dunnick, Y. Tor, Inorg. Chem. 37 (1998) 1121.

[7] (a) F.R. Lembke, D.J. Szallda, R.M. Bullock, J. Am. Chem. Soc. 113 (1991) 8466. (b) Y. Hayashi, M. Osawa, K. Kobayashi, Y. Wakatsuki, Chem. Commun. (1996) 1617. (c) C. Qian, J. Guo, J. Sun, J. Chen, P. Zheng, Inorg. Chem. 36 (1997) 1286. (d) X. Yin, J.R. Moss, J. Organomet. Chem. 557 (1998) 259. (e) S. Back, H. Pritzkow, H. Lang, Organometallics 17 (1998) 41.

[8] G.A. Razuvaev, G.A. Domrachev, V.V. Sharutin, O.N. Suvorova, J. Organomet. Chem. 141 (1977) 313.

[9] S. Back, L. Zsolnai, G. Huttner, H. Lang, J. Organomet. Chem. 563 (1998) 73.

[10] (a) H. Lang, K. Köhler, S. Blau, Coord. Chem. Rev. 143 (1995) 113 and refs. cited therein. (b) G. Schmidt, N. Schittenhelm, U. Behrens, J. Organomet. Chem. 496 (1995) 49. (c) M.D. Jansen, M. Herres, L. Zsolnai, D.M. Grove, A.L. Spek, H. Lang, G. van Koten, Organometallics 14 (1995) 1098.

[11] (a) J.L. Atwood, G.K. Barker, J. Holton, W.E. Hunter, M.F. Lappert, R. Pearce, J. Am. Chem. Soc. 99 (1977) 6645. (b) H. Yasuda, Y. Kajihara, K. Mashima, N. Nagasuna, K. Lee, A. Nakamura, Organometallics 1 (1982) 388.

[12] (a) H. Lang, D. Seyferth Z. Naturforsch. 45b (1990) 212. (b) M.D. Janssen, K. Köhler, M. Herres, A. Dedieu, W.J.J. Smeets, A.L. Spek, D.M. Grove, H. Lang, G. van Koten, J. Am. Chem. Soc. 118 (1996) 4817. (c) H. Lang, I.-Y. Wu, S. Weinmann, C. Weber, B. Nuber, J. Organomet. Chem. 541 (1997) 157. 
[13] Ti: (a) H. Lang, M. Herres, L. Zsolnai, Organometallics 12 (1993) 5008. (b) For related $\left(\eta^{5}-\mathrm{C}_{5} \mathrm{H}_{5}\right)_{2} \mathrm{Ti}\left(\mathrm{C} \equiv \mathrm{CSiMe}_{3}\right)_{2}$ see: G.L. Wood, M.F. Hawthorne, Inorg. Chem. 28 (1989) 382. Hf: (c) J. Kralik, Diplom-Thesis, University Heidelberg, Germany, 1995.

[14] Ti: (a) K. Köpf, M. Schmidt, J. Organomet. Chem. 10 (1967) 383. (b) H. Lang, W. Imhof Chem. Ber. 125 (1992) 1307. Zr: (c) G. Erker, H. Frömberg, R. Benn, R. Mynott, K. Angermund, C. Krüger, Organometallics 8 (1989) 911. (d) H. Lang, D. Seyferth Appl. Organomet. Chem. 4 (1990) 599. Hf: (e) H. Lang, M. Herres, L. Zsolnai, Bull. Chem. Soc. Jpn. 66 (1993) 1.

[15] H. Lang, M. Weinmann, Synlett (1996) 1 and refs. cited therein.

[16] For detailed discussion see: (a) H. Lang, S. Blau, B. Nuber, L. Zsolnai, Organometallics 14 (1995) 3216. (b) K. Köhler, S.J. Silverio, I. Hyla-Kryspin, R. Gleiter, A. Driess, G. Huttner, H. Lang, Organometallics 16 (1997) 4970 and refs. cited therein.

[17] J. Dale, in: H.G. Viehe (Ed.), Chemistry of Acetylenes, Marcel Dekker, New York, 1969.

[18] (a) K.C. Ott, R.H. Grubbs, J. Am. Chem. Soc. 103 (1981) 5922. (b) P. Binger, P. Müller, R. Wenz, R. Mynott, Angew. Chem. 102 (1990) 1070; Angew. Chem. Int. Ed. Engl. 29 (1990) 1037. (c) G.A. Luinstra, J.H. Teuben, Organometallics 11 (1992) 1793. (d) R. Beckhaus Angew. Chem. 109 (1997) 694; Angew. Chem. Int. Ed. Engl. 36 (1997) 686. (e) R. Beckhaus, J. Oster, R. Wang, K. Böhme, Organometallics 17 (1998) 2215.

[19] H. Lang, S. Blau, H. Pritzkow, L Zsolnai, Inorg. Chem. 34 (1995) 1850.

[20] J.J. Eisch, K.R. Caldwell, S. Werner, C. Krüger, Organometallics 10 (1991) 3417.

[21] U. Thewalt, T. Wöhrle, J. Organomet. Chem. 464 (1994) C17.

[22] J. Scholz, F. Rehbaum, K.-H. Thiele, R. Goddard, P. Betz, K.-H. Krüger, J. Organomet. Chem. 443 (1993) 93.

[23] (a) B. Bartkowska, C. Krüger, Acta Crystallogr. C 53 (1997) 1066. (b) J. Bruckmann, C. Krüger, Acta Crystallogr. C 53 (1997) 1845. (c) J. Garcia, B. Asfaw, A. Rodriguez, F.R. Fronczek, Acta Crystallogr. C 54 (1998) 489.

[24] (a) A. Clearfiled, D.K. Werner, C.H. Saldarriega-Molina, R. Ropal, I. Bernal, Can. J. Chem. 173 (1979) 175. (b) V.B. Rybakov, U. Thewalt, V. Varga, K. Mach, J. Organomet. Chem. 447 (1993) 221.

[25] H. Lang, C. Weber, Organometallics 14 (1995) 4415.

[26] M. Herres, H. Lang, J. Organomet. Chem. 480 (1994) 235.
[27] (a) P.M. Fritz, K. Polborn, M. Steinmann, W. Beck, Chem. Ber. 122 (1989) 889. (b) U. Pidun, G. Frenking, Organometallics 14 (1995) 5325. (c) S. Lotz, P.H. van Rooyen, R. Meyer, Adv. Organomet. Chem. 37 (1995) 219.

[28] (a) F. Ohlbrich, G. Schmidt, U. Behrens, E.J. Weiss, J. Organomet. Chem. 418 (1991) 421. (b) G. Gröger, F. Ohlbrich, E.J. Weiss, U. Behrens, J. Organomet. Chem. 514 (1995) 81.

[29] (a) M.I. Bruce, R. Clark, J. Howard, P. Woodward, J. Organomet. Chem. 42 (1972) C107. (b) W. Beck, B. Niemer, J. Breitmaier, J. Heidrich, J. Organomet. Chem. 371 (1989) 79. (c) J. Heidrich, M. Steinamnn, M. Appel, W. Beck, J.R. Phillipps, W.C. Trogler, Organometallics 9 (1990) 1296.

[30] A.J. Jukes, Adv. Organomet. Chem. 12 (1974) 215.

[31] H. Lang, W. Frosch, I.Y. Wu, S. Blau, B. Nuber, Inorg. Chem. 35 (1996) 6266.

[32] B.N. Storhoff, H.C. Lewis, Coord. Chem. Rev. 23 (1977) 1.

[33] S. Back, R.A. Gossage, M. Albrecht, M. Lutz, A.L. Spek, H. Lang, G. van Koten, Organometallics, submitted for publication.

[34] (a) L.B. Kool, M.D. Rausch, K.G. Alt, M. Herberhold, U. Thewalt, B. Wolf, Angew. Chem. 97 (1985) 425; Angew. Chem. Int. Ed. Engl. 24 (1985) 413. (b) P. Binger, P. Müller, P. Phillipps, B. Gabor, R. Mynott, A.T. Herrmann, F. Langhauser, C. Krüger, Chem. Ber. 125 (1992) 2209.

[35] M.-C. Lagunas, R.A. Gossage, W.J.J. Smeets, A.L. Spek, G. van Koten, Eur. J. Inorg. Chem. 4 (1998) 163.

[36] R.A.T.M. Abbenhuis, I. del Río, M.M. Bergshoef, J. Boersma, N. Veldman, A.L. Spek, G. van Koten, Inorg. Chem. 37 (1998) 1749.

[37] (a) S.P. Gubin, S.A. Smirnova, J. Organomet. Chem. 20 (1969) 229. (b) N. El Murr, A. Chalayord, J. Trouflet, J. Chem. Soc. Chem. Commun. (1980) 447.

[38] A.-C. Ribou, J.-P. Launay, M.L. Sachtleben, H. Li, C.W. Spangler, Inorg. Chem. 35 (1996) 3735.

[39] S.L. James, G. Verspui, A.L. Spek, G. van Koten, Chem. Commun. (1996) 1309.

[40] S. Takakashi, Y. Kuroyama, K. Sonogashira, N. Hagihara, Synthesis (1980) 627.

[41] L. Della Ciana, A. Haim, J. Heterocycl. Chem. 221 (1984) 607.

[42] G. Doisnaeu, G. Balavoine, T. Fillibeen-Khan, J. Organomet. Chem. 425 (1992) 113.

[43] G.J. Kubas, Inorg. Synth. 19 (1979) 90. 